Çukurova Üniversitesi Eğitim Fakültesi Dergisi

Vol:46 No:1 Sayfa:134-164

\title{
Science Teachers and Pre-Service Science Teachers' Scientific Epistemological Beliefs and Opinions on the Nature of Science ${ }^{*}$
}

\author{
Fatma Adak $^{\text {a }}$, Selda BAKIR ${ }^{\text {b. }}$ \\ ${ }^{a}$ MEB. Hoşgör Ortaokul,Gaziantep/Türkiye \\ ${ }^{\mathrm{b}}$ MAKU.Eğitim Fakültesi, Burdur/Türkiye
}

CrossMark

\section{Article Info}

DOI: 10.14812/cuefd.309443

Keywords:

Nature of science,

Scientific epistemological belief,

Pre-service science teachers,

Science teachers.

\begin{abstract}
In this study that was conducted to determine science teachers' and pre-service science teachers' epistemological beliefs and opinions about the nature of science, the study group constituted of 236 pre-service science teachers and 61 science teachers working in secondary schools. In this study conducted with mixed research pattern, as data collection tools, "ScientificEpistemological Beliefs Survey" and "Perspectives on Scientific Epistemology Scale" were used. As a result of the research, according to findings obtained from "Scientific Epistemological Beliefs Survey," it was concluded that science teachers and pre-service science teachers have a traditional understanding of science and there was not significant differences between scientific epistemological beliefs among science teachers and pre-service science teachers. According to the findings obtained from "Perspectives on Scientific Epistemology Scale," it has been revealed that both groups have traditional understanding of science based on positivist paradigm especially towards "source of scientific knowledge, scientific theories and laws", and non-traditional (contemporary) scientific understanding based on post-positivist paradigm towards "changeable nature of scientific knowledge; nature of scientific knowledge to be based on evidences and observations; observations, inferences and theoretical titles in science; creative nature of scientific knowledge; subjectivity and social and cultural structure of scientific knowledge".
\end{abstract}

\section{Fen Bilimleri Öğretmenleri ve Fen Bilgisi Öğretmen Adaylarının Bilimsel Epistemolojik İnançları ve Bilimin Doğası Hakkındaki Görüşleri}

Makale Bilgisi

DOI: $10.14812 /$ cuefd.309443

Anahtar Kelimeler:

Bilimin doğası,

Bilimsel epistemolojik inanç,

Fen bilgisi öğretmen adayları,

Fen bilimleri öğretmenleri.

\section{Öz}

Fen bilimleri öğretmenlerinin ve fen bilgisi öğretmen adaylarının epistemolojik inançları ve bilimin doğasına dair görüşlerini belirlemek için yapılan bu araştırmanın çalışma grubunu, 236 fen bilgisi öğretmen adayı ve ortaokullarda görev yapan, 61 fen bilimleri öğretmeni oluşturmaktadır. Karma araştırma deseniyle yapılan bu araştırmada veri toplama aracı olarak, "BilimselEpistemolojik İnançlar Ölçeği" ve "Bilimsel Epistemoloji Üzerine Görüşler Anketi" kullanılmıştır. Araştırma sonucunda, "Bilimsel Epistemolojik İnanç Ölçeği" nden elde edilen bulgulara göre fen bilimleri öğretmenlerinin ve öğretmen adaylarının geleneksel bilim anlayışına sahip oldukları ve fen bilimleri öğretmenleri ile fen bilgisi öğretmen adaylarının bilimsel epistemolojik inançları arasında anlamlı bir farkın olmadığı sonucuna ulaşılmıştır. "Bilimsel Epistemoloji Üzerine Görüşler Anketi" nden elde edilen bulgulara göre ise, her iki grubun da "bilimsel bilginin kaynağı, bilimsel teoriler ve kanunlar" özelliklerine yönelik

\footnotetext{
* This study is a part of master thesis made by Fatma Adak, completed at Mehmet Akif Ersoy University Institute of Educational Sciences in 2016, under the supervision of Assist.Prof. Selda Bakır, and suppported by Mehmet Akif Ersoy University Scientific Research Comission with 0220-YL-14 project number.

† Corresponding Author: sbakir@mehmetakif.edu.tr
} 
pozitivist paradigmaya dayanan geleneksel bilim anlayışına, "bilimsel bilginin değişebilirliği, bilimsel bilginin doğasının deney ve gözlemlerden elde edilen kanıtlara dayalı olması, gözlemler, çıkarımlar ve bilimde teorik başlıklar, bilimsel bilginin yaratıcı doğası, öznellik ve bilimsel bilginin sosyal ve kültürel yapısı" özelliklerine yönelik ise, post-pozitivist paradigmaya dayanan geleneksel olmayan (çağdaş) bilim anlayışına sahip oldukları tespit edilmiştir.

\section{Introduction}

Epistemology can be expressed as a field of philosophy that criticizes the problems related to knowledge, that examines where the information comes from, its structure, origin, criteria, validity and limitations (Hançerlioğlu, 1996; Yazıcı, 1999; Çüçen, 2001; Deryakulu, 2006; Cevizci, 2010). Epistemology, which is one of the basic structures of philosophy, analyzes the nature of human knowledge, scope of knowledge, its origins, limitations, conceptual components, accuracy and validity in all respects. Epistemology includes research fields that can be associated with three basic questions. These questions include; "What are the limits of human knowledge?", "What are the resources of human knowledge?" and "What is the nature of human knowledge?" (Muis, Bendixen \& Haerle, 2006). Belief, on the other hand, are individuals' acceptances that constitute their perceptions, interpretation and attitudes towards these interpretations (Deryakulu, 2006). According to Hofer and Pintrich (1997), behind all precise judgments and exhibited behaviors lie individuals' beliefs. Individuals' beliefs about knowledge, knowing and learning are called epistemological beliefs (Schommer, 1990; Deryakulu \& Büyüköztürk, 2005). Scientific epistemological belief, on the other hand, covers individuals' beliefs about what science and scientific knowledge are, how are they produced and shared, and how should they be taught (Deryakulu \& Bıkmaz, 2003).

There are two important paradigms about the formation of scientific knowledge. According to positivist paradigm, scientific experience is quite important in the formation of scientific knowledge, only knowledge that is observed through observed and controlled experimental studies is reliable (Ekiz, 2009) and scientific knowledge is single and absolute truths (Özden, 2003). However, science is not the outcome of neither pure reason nor pure observation (Yıldırım, 2014). According to post-positivist paradigm, scientific knowledge is the knowledge that is not only based on experiment, observation and used method, but also based on conditions of the society and age in which science is done, and scientific truths and judgments are not absolute (Özden, 2003). Contemporary conception of scientific epistemological beliefs has shifted from traditional scientific understanding based on positivist paradigm towards non-traditional conception of science based on post-positivist paradigm and based on the fact that scholars are under the effect of culture and society they live in, and individual beliefs and values, imagination and instincts (Pomeroy, 1993).

In particular, in studies conducted towards science education, it is seen that concepts such as epistemological beliefs, epistemological opinions and scientific knowledge are used in the same sense (Çoban \& Ergin, 2008). In addition to these terms, the nature of science is used for the same purpose. In the study conducted by Çoban and Ergin (2008), it can be seen that while the characteristic of scientific knowledge is discussed, characteristics in questions are of the nature of science. The same study of scientific knowledge, "the nature of scientific knowledge, the data source, the value, the accuracy limits of debate" that supports this thesis. In this study, epistemological beliefs, scientific knowledge and nature of science are used in the same sense.

Although Khishfe and Abd-El Khalick (2002) indicate that the nature of science cannot be defined completely due to complex, dynamic and multiple structure of science, Lederman (2007; cited by Akgün, 2015) defines the nature of science as the whole of beliefs and values that reflect epistemology of science and that are included in the way of knowledge creation and production of knowledge. Features of nature of science (scientific knowledge) can be grouped under the following topics (Doğan, Çakıroğlu, Bilican \& Çavuş, 2009).

\section{$\checkmark \quad$ Changeable nature of scientific knowledge}


$\checkmark \quad$ Nature of scientific knowledge based on evidence obtained from experiment and observations

$\checkmark$ Subjectivity

$\checkmark \quad$ Creative nature of scientific knowledge

$\checkmark$ Social and cultural structure of scientific knowledge

$\checkmark$ Observations, inferences and theoretical titles in science

$\checkmark$ Scientific theories and laws

The subject of how individuals consider the nature of science draws the attention of educational researchers day by day. There are several studies finding out that, due to individualistic differences, individuals tend to have different perspectives towards events and facts and each individual has their peculiar epistemology (Evcim, 2010) and these beliefs have significant effects on learning (Hofer, 2001; Öngen, 2003; Deryakulu \& Büyüköztürk, 2005; Deryakulu, 2006; Eroğlu \& Güven 2006). For example, Deryakulu (2004) concluded that, during the process of learning, students with developed epistemological beliefs are more successful academically based on their increased usage of qualified learning strategies when compared to students with underdeveloped epistemological beliefs. While YIImaz and Delice (2007) suggest that, despite having enough knowledge in problem solving, pre-service teachers' beliefs negatively affect their achievement, Izgar and Dilmaç (2008) and Gürol, Altunbaş and Karaaslan (2010) suggest that teachers with high level of self-perception also have higher level of epistemological beliefs. Schommer and Walker (1997), in their study in which they analyzed the relationship between university students' attitudes towards school and their epistemological beliefs, conclude that students, who strongly believe that learning skill comes from birth and it is an irrevocable skill, tend to care for school less and believe in the value of education less when compared to students, who believe that learning skill can be improved.Chan (2002) has concluded in a study conducted with pre-service teachers in Hong Kong, Institute of Education, that pre-service teachers believing that learning depends of effort and process adopt thorough learning approach for meaning learning, on the other hand, pre-service teachers believing that knowledge should be provided by an authority or an expert adopt superficial learning approach. In addition, scientific epistemological beliefs have a decisive effect on people's preferred teaching-learning approaches, learning strategies, perception and interpretation methods of knowledge and experiences (Deryakulu \& Barge, 2003).

Educating scientific literate individuals is placed in the center of education programs in many countries (Lederman, 1992; Abd-El-Khalick, 2001; Doğan, 2010; MEB, 2013; Akgün, 2015). In the most broader terms, a scientific literate person should be able to develop an understanding towards the complex relationship between concepts, theories, principles, scientific processes and science, technology and society, and more importantly towards the nature of science (Abd-El-Khalick \& BouJaoude, 1997). It has become important in terms of functionality of education programs to determine opinions towards the nature of scientific knowledge (scientific epistemological beliefs) among teachers who will educate the target population, namely students who are expected to become scientific literate people. When the related literature is reviewed, it has been revealed that there are many studies on epistemological beliefs among pre-service teachers (Öngen, 2003; Deryakulu \& Büyüköztürk, 2005; Terzi, 2005; Eroğlu \& Güven, 2006; Yılmaz \& Delice, 2007; Ayaz, 2009; Meral \& Çolak, 2009; Öztürk, 2009; Öztürk, 2011), but there are less number of studies on teachers' epistemological beliefs (Izgar \& Dilmaç, 2008; Ayvacı \& Nas, 2010; Akçay, 2011). In this regard, the research sample was determined as pre-service science teachers and science teachers. In this study that was conducted to determine science teachers' and pre-service science teachers' scientific epistemological beliefs and their opinions on the nature of science, answers to the following questions were searched:

1. What is the level of scientific epistemological beliefs among pre-service science teachers?

2. What is the level of scientific epistemological beliefs among science teachers?

3. Are there any significant differences between science teachers' scientific epistemological beliefs and those of pre-service science teachers? 
4. What are the opinions of science teachers and pre-service science teachers on the nature of science?

\section{Method}

This study was based on mixed research pattern. Mixed research method is the research pattern in which quantitative and qualitative data or techniques are combined (Christensen, Johnson \& Turner, 2015). The current study, therefore, is a mixed study in terms of containing qualitative and quantitative data. In the study, quantitative data was collected through scanning model, and qualitative data was collected through phenomenological analysis. In the study, some measures, valid for mixed studies, were taken to ensure validity and reliability. The first one among these measures was the weakness minimization validity that was based on researcher's use of another method to cover up weakness of a method (Christensen, Johnson \& Turner, 2015). In-depth knowledge, which was the lack of quantitative data, was obtained through quantitative ways. The second one was the multiple validity that was based on the comparison of specific validities within appropriate quantitative, qualitative and mixed methods (Christensen, Johnson \& Turner, 2015). Another measure taken for qualitative data was triangulation. Triangulation can be in three forms including data sources, method and researcher triangulation (Patton, 2014). In this study, data sources, researcher triangulation and method triangulation were used. As for data source, science teachers and pre-service science teachers were selected. To ensure diversity among participants, teachers were selected from both schools located in city center and from central districts, on the other hand, pre-service science teachers were selected from 1st, 2nd, 3rd and 4 th grades of science teaching program. For method diversity, scanning and phenomenology patterns were used. In terms of researcher diversity, the study was conducted by two researchers. Thus, the aim was to avoid researches' subjective judgments as much as possible.

\section{Participantsand Data Collection Procedure}

Study group of the research consists of 61 science teachers working in secondary schools in Burdur city center and its districts and 236 pre-service science teachers attending the 1st, 2nd, 3rd and 4th grades of Science Teaching Program in the Faculty of Educational Sciences as of 2013-2014 academic year and all selected through the stratified purposive sampling method. According to Büyüköztürk, Çakmak, Akgün, Karadeniz and Demirel (2009:91), "Differing from stratified sampling with its feature of not considering randomness in unit selection, the stratified purposeful sampling is also known as quota sampling in the literature." The reason for selecting this sampling method for pre-service teachers was that it was considered more appropriate to include pre-service teachers from all grade levels in the sample. All these two groups were applied with "ScientificEpistemological Beliefs Survey" in which quantitative data was collected. "Perpectives on Scientific Epistemology Scale," in which qualitative data was collected, was applied to 85 pre-service science teachers and 40 science teachers selected randomly from the study sample, but 28 of the pre-service science teachers and 10 of the science teachers were excluded from the study since they could not fill in scales completely. In the final situation, the qualitative data was collected from 57 pre-service science teachers and 30 science teachers.

\section{Instruments}

Scientific Epistemological Beliefs Survey. ScientificEpistemological Beliefs Survey was developed by Pomeroy (1993). This scale is composed of 50 items under three subdimensions in English in its original form. Translated into Turkish by Deryakulu and Bıkmaz (2003), the scale consists of 30 items in total including 22 positive items reflecting traditional conception of science and 8 negative items reflecting non-traditional conception of science as a result of validity and reliability analyses. Alpha internal consistency coefficient calculated for the original form of the scale translated into Turkish is .91 (Deryakulu and Bıkmaz, 2003). The scale has a five point Likert-type ranging from (1) I Strongly Agree to (5) I Strongly Disagree. The lowest score that can be obtained from the scale is 1 , and the highest score is 5. High score (>2.5) obtained from the scale indicates strong belief in traditional understanding of science, and low score $(<2.5)$ indicates non-traditional (contemporary) understanding of science. 
Perpectives on Scientific Epistemology Scale. Opinions on Scientific Epistemology Scale was developed by Abd-El-Khalick (2002). This survey consists of 10 open-ended questions. The survey was adapted by Doğan (2010), and reviews by two experts were taken for content validity. From the scale, consisting of 10 questions in its original form, 8 questions were used for this study. Questions cover the following features of the nature of science;

- Changeable nature of scientific knowledge

- Nature of scientific knowledge is based on evidence and observation.

- Subjectivity

- Creative nature of scientific information

- Social and cultural structure of scientific knowledge

- Scientific theories and laws

- Observations, inferences and theoretical titles in science (evidence and data).

\section{Data Analysis}

For analyses of scientific epistemological belief scale that constituted quantitative data of the research, single factor analysis of variance (One-Way ANOVA) was applied for descriptive analysis and unrelated samples by considering normal distribution of scores by pre-service teachers and teachers. For the analysis of scores obtained from "Scientific Epistemological Beliefs Survey" that constituted quantitative data of the research, total scores obtained from all items in the scale were used. Cronbach Alpha reliability coefficient of the scale, in which quantitative data was obtained, was calculated as .91 for this study. Qualitative data of the research was collected from participants' answers to "Perspectives on Scientific Epistemology Scale". Qualitative data was analyzed using the content analysis, one of the qualitative analysis methods. In the content analysis, data is subjected to an in-depth examination, similar data was combined around certain themes and concepts (Yıldırım \& Şimşek, 2008). In this context, surveys read repeatedly by researchers were subjected to content analysis, similar data were encoded, and themes that would express these codes were established. To ensure reliability and consistency in analysis of the data in the research, the same data set was encoded by both researchers, and consistency between encoders was considered. Consistency was calculated using "Consensus (Consensus+Dissidence) $\times 100$ " formula (Miles \& Huberman, 1994). As a result of this calculation, 0.87 percent consistency was determined among analysis results obtained by researchers. Besides, direct quotes were used for external validity in data.

\section{Results}

\section{Findings related to the First Sub-Problem}

Results of descriptive analysis towards pre-service science teachers' scores obtained from "Scientific Epistemological Belief Survey" are presented in Table 1.

Table 1.

Results of Descriptive Analysis towards Pre-service Science Teachers' Scientific Epistemological Beliefs Scores

\begin{tabular}{llllll}
\hline Variable & $\mathrm{N}$ & Min & Max & $\overline{\mathrm{X}}$ & $\mathrm{SD}$ \\
\hline $\begin{array}{l}\text { Scientific } \\
\begin{array}{l}\text { Epistemological } \\
\text { Beliefs }\end{array}\end{array}$ & 236 & 2.97 & 3.93 & 3.48 & .197 \\
\hline
\end{tabular}

As can be seen in Table 1, it can be said that, based on pre-service science teachers' higher average score $(X=3.48, S D=.197)$ from Scientific Epistemological Beliefs Survey, pre-service science teachers have a traditional understanding of science. 


\section{Findings related to the Second Sub-Problem}

Results of descriptive analysis conducted to determine science teachers' levels of scientific epistemological beliefs are presented in Table 2.

Table 2.

Results of Descriptive Analysis towards Science Teachers' Scientific Epistemological Beliefs Scores

\begin{tabular}{llllll}
\hline Variable & $\mathrm{N}$ & Min & Max & $\overline{\mathrm{X}}$ & $\mathrm{SD}$ \\
\hline $\begin{array}{l}\text { Scientific } \\
\begin{array}{l}\text { Epistemological } \\
\text { Beliefs }\end{array}\end{array}$ & 61 & 2.83 & 4.00 & 3.50 & .22 \\
\hline
\end{tabular}

Analyzing the Table 2, it can be said that, based on higher average scores ( $X=3.50, S D=.22$ ) from Scientific Epistemological Beliefs Survey, science teachers have a traditional understanding of science.

\section{Findings related to the Third Sub-Problem}

Results of One-Way ANOVA conducted to analyze the difference between levels of scientific epistemological beliefs among science teachers and pre-service science teachers are presented in Table 3.

\section{Table 3.}

Results of One-Way ANOVA Test towards Science Teachers and Pre-service Science Teachers' Scientific Epistemological Beliefs

\begin{tabular}{llllll}
\hline Source of Variance & $\begin{array}{l}\text { Sum of } \\
\text { Squares }\end{array}$ & $\mathrm{df}$ & Mean Square & $\mathrm{F}$ & $\mathrm{P}$ \\
\hline Between Groups & .024 & 1 & .024 & .594 & $.442^{*}$ \\
Within Groups (error) & 12.089 & 295 & .041 & & \\
Total & 12.114 & 296 & & & \\
\hline
\end{tabular}

${ }^{*} \mathrm{p}>.05$

As can be seen in Table 3, as a result of the variance analysis applied, no significant differences were found $\left(F_{1-295}=0.594 ; p>.05\right)$ between science teachers' scientific epistemological beliefs scores $(X=3.47$, $\mathrm{SD}=.19)$ and pre-service science teachers' scientific epistemological beliefs scores $(X=3.50, S D=.22)$.

\section{Findings related to the Fourth Sub-Problem}

Findings are given in the forms of headlines associated with features of the nature of science.

Source of Scientific Knowledge. Findings obtained as a result of the analysis of data that was obtained from opinions of the participants on the source of scientific knowledge are given in Table 4.

Table 4.

Findings related to the Theme "The Source of Scientific Knowledge"

\begin{tabular}{lrccc}
\hline Sub-Themes & \multicolumn{2}{c}{ Pre-service Teachers } & \multicolumn{2}{l}{ Teachers } \\
& $\mathrm{f}$ & $\%$ & $\mathrm{f}$ & $\%$ \\
\hline Just experiment and & 19 & 33.92 & 8 & 28.57 \\
observation & & & & \\
Accidentally & 13 & 23.21 & 3 & 10.71 \\
Scientific method & 6 & 10.71 & 6 & 21.42 \\
Research and analysis & 6 & 10.71 & 0 & 0 \\
Curiosity & 4 & 7.14 & 3 & 10.71
\end{tabular}


Fatma Adak, Selda BAKIR - Çukurova Üniversitesi Eğitim Fakültesi Dergisi, 46(1), 2017, 134-164

\begin{tabular}{lllll} 
Based on needs & 3 & 5.35 & 4 & 14.28 \\
Trial and error & 3 & 5.35 & 0 & 0 \\
Thinking & 2 & 3.57 & 2 & 7.14 \\
Technology & 0 & 0 & 2 & 7 \\
\hline
\end{tabular}

According to Table 4, it is observed that opinions of both pre-service teachers and teachers concentrate on "only experiment and observation". While experiment and observation, one of the preservice teachers' opinions, is followed respectively by accidentally, scientific method, research and analysis, curiosity, needs and trial-and-error; teachers' opinions are also accumulated around similar themes. It attracts attention that mostly "scientific method" opinion is common only after experiment and observation, and teachers mentioned about the theme of "technology" that pre-service teachers never mentioned. Besides, vast majority of teachers and pre-service teachers, who mentioned that experiment was used is the production of scientific knowledge, answered the question of "will you use a miraculous liquid that will grow your flower faster without using scientific ways?" by saying "they will not try something like this". According to these findings, it can be said that science teachers and preservice science teachers have a traditional understanding of science with regard to "source of scientific knowledge." Direct quotation example regarding this theme is given below.

"This miraculous liquid was tested with controlled experiments before their shipment to market shelves. Therefore, there is no need for me to try. Already, it's going to work"... (PST-41 [Traditional understanding of science].

Changeability of Scientific Knowledge. Findings related to science teachers' and pre-service science teachers' opinions on the feature of the nature of science, "changeability of scientific knowledge" can be seen in Table 5.

Table 5.

Findings Related to the Theme "Changeability of Scientific Knowledge"

\begin{tabular}{lllll}
\hline Sub-Themes & \multicolumn{2}{c}{ Pre-service Teachers } & \multicolumn{2}{c}{ Teachers } \\
& $\mathrm{f}$ & $\%$ & $\mathrm{f}$ & $\%$ \\
\hline Changes with technological developments & 17 & 32.69 & 8 & 28.57 \\
Varies with the progress of science & 12 & 23.07 & 7 & 25 \\
Changes with research and experiment & 7 & 13.46 & 2 & 7.14 \\
Changes with new thinking and & 6 & 11.53 & 4 & 14.28 \\
interpretations & & & & \\
Theories vary & 4 & 7.69 & 5 & 17.85 \\
Law do not change & 3 & 5.76 & 0 & 0 \\
Information does not change & 2 & 3.84 & 0 & 0 \\
Changes with the requirements of the age & 1 & 1.92 & 2 & 7.14 \\
\hline
\end{tabular}

Analyzing the Table 5, it can be seen that, while a few opinions by pre-service teachers are towards irrevocable feature of laws and knowledge, vast majority of opinions by pre-service teachers and all opinions by teachers are towards that the fact that scientific knowledge can be changed with the developments in science, technological developments, theories, new thinking and interpretations, research and experiments or based on requirements of the age. Accordingly, it can be said that preservice teachers and science teachers have non-traditional conception of science with regard to features of the nature of science "changeability of scientific knowledge". Direct quotation examples regarding this theme are given below.

... "Science and knowledge are not static, knowledge also varies with research and technological developments..." (ST-29 [Non-traditional conception of science]) 
... "Scientific knowledge may change in accordance with newly produced ideas and hypotheses introduced. It is not static." (PST-37 [Non-traditional conception of science])

Nature of Scientific Knowledge is Based on Evidence and Observation/Observations, Inferences and Theoretical Titles in Science. Findings relating to science teachers' and pre-service science teachers' opinions towards the features of the nature of science such as "nature of scientific knowledge is based on evidence and observation" and "observations, inferences and theoretical titles in science" are shown in Table 6.

Table 6

Findings related to Themes of "Nature of Scientific Knowledge is Based on Evidence and Observation" and "Observations, Inferences and Theoretical Titles in Science"

\begin{tabular}{|c|c|c|c|c|}
\hline \multirow[t]{2}{*}{ Sub-Themes } & \multicolumn{2}{|c|}{ Pre-service Teachers } & \multicolumn{2}{|c|}{ Teachers } \\
\hline & \multicolumn{2}{|c|}{$f \%$} & \multicolumn{2}{|c|}{$\mathrm{f} \%$} \\
\hline \multicolumn{5}{|l|}{ Evidence } \\
\hline Proof & 19 & 38 & 16 & 59.25 \\
\hline Hint, trace & 9 & 18 & 3 & 11.11 \\
\hline Information based on experiment and observation & 7 & 14 & 4 & 14.81 \\
\hline Proof of truth & 6 & 12 & 0 & 0 \\
\hline Suggestions & 5 & 10 & 4 & 14.81 \\
\hline The foundation of research & 4 & 8 & 0 & 0 \\
\hline \multicolumn{5}{|l|}{ Data } \\
\hline Gather information & 23 & 45.09 & 5 & 19.23 \\
\hline Qualitative and quantitative information & 10 & 19.60 & 14 & 53.84 \\
\hline Main element forming the basis of research & 7 & 13.72 & 2 & 7.69 \\
\hline The values at the end of research & 5 & 9.80 & 1 & 3.84 \\
\hline Written materials & 3 & 5.88 & 0 & 0 \\
\hline Information divided into stages & 3 & 5.88 & 0 & 0 \\
\hline Raw form of information & 0 & 0 & 4 & 15.38 \\
\hline \multicolumn{5}{|l|}{ Collection of data and evidences } \\
\hline Observation & 13 & 22.41 & 7 & 20.58 \\
\hline Questionnaire & 10 & 17.24 & 4 & 11.76 \\
\hline Research / Examination & 8 & 14.54 & 2 & 5.88 \\
\hline Experiment / Controlled experiment & 7 & 12.06 & 5 & 14.70 \\
\hline Meeting / interview & 6 & 10.34 & 2 & 5.88 \\
\hline Journey / Observation & 4 & 6.89 & 3 & 8.82 \\
\hline Analysis of works & 3 & 5.17 & 5 & 14.70 \\
\hline Archive investigation & 3 & 5.17 & 2 & 5.88 \\
\hline Scientific methods & 2 & 3.44 & 1 & 2.94 \\
\hline Internet & 2 & 3.44 & 2 & 5.88 \\
\hline Nature research & 0 & 0 & 1 & 2.94 \\
\hline
\end{tabular}

Analyzing the Table 6, it has been determined that, while opinions of pre-service teachers focus on themes such as evidence, tips and trails, knowledge based on testing and observation, proof of truth, proposition and proof and the basis of research respectively, teachers' opinions focus on similar themes with exception of themes such as proof of truth and basis of research. In addition, it has been determined that most of the teachers consider proof as "evidence". It has been observed that teachers' and pre-service teachers' opinions towards data focus on themes such as qualitative and quantitative knowledge, collecting information, raw form of information, values at the end of research, main element forming the basis of research. In addition to these sub-themes, other themes such as written materials and fragmented form of knowledge are found among pre-service teachers despite being few 
in numbers. While pre-service teachers define data as "collecting information", teachers mostly define it as "qualitative and quantitative information". While it is seen that the vast majority of pre-service teachers' answers related to data and evidence collection methods include observation, survey, research/review, experiment/controlled experiment and meeting/interview, on the other hand, the vast majority of teachers' opinions concentrate on observation, experiment/controlled experiment, analysis of works and survey. Based on all these findings, it can be said that science teachers and pre-service science teachers exhibit non-traditional conception understanding of science related to the features of the nature of science such as "nature of scientific knowledge is based on evidence and observation" and "observations, inferences and theoretical titles in science". Below are examples of direct quotes about this theme.

... "Evidence consists of information that we collect for solving a problem and that will verify the hypothesis." (ST-8 [Non-traditional conception of science])

..."Quantitative and qualitative information obtained as a result of experiments and observations is called data..." (ST-9 [Non-traditional conception of science])

Scientific Theories and Laws. Findings related to science teachers' and pre-service science teachers' opinions on the feature of the nature of science, "scientific theories and laws" are given in Table 7.

Table 7.

"Scientific Theories and Laws" Theme

\begin{tabular}{|c|c|c|c|c|}
\hline \multirow{2}{*}{$\begin{array}{l}\text { Sub-Themes } \\
\text { Theory }\end{array}$} & \multicolumn{2}{|c|}{$\begin{array}{l}\text { Pre-service Teachers } \\
\mathrm{f} \%\end{array}$} & \multicolumn{2}{|c|}{$\begin{array}{l}\text { Teachers } \\
\text { f \% }\end{array}$} \\
\hline & & & & \\
\hline Knowledge with its accuracy widely accepted & 11 & 17.18 & 10 & 23.25 \\
\hline $\begin{array}{l}\text { Hypothesis proven with experiment and } \\
\text { observation }\end{array}$ & 10 & 15.62 & 15 & 34.88 \\
\hline Experiment results not accepted by everybody & 9 & 14.06 & 5 & 11.62 \\
\hline Facts likely to be refuted & 8 & 12.05 & 2 & 4.65 \\
\hline Experiment result considered by many scientists & 7 & 10.93 & 3 & 9.30 \\
\hline $\begin{array}{l}\text { Hypotheses that are accepted but likely to be } \\
\text { falsified }\end{array}$ & 6 & 9.37 & 4 & 9.30 \\
\hline Scientific proposition not yet proven & 5 & 7.81 & 1 & 2.32 \\
\hline Scientific facts & 3 & 4.68 & 3 & 6.97 \\
\hline Description of information & 3 & 4.68 & 0 & 0 \\
\hline Vision hard to prove & 2 & 3.12 & 0 & 0 \\
\hline \multicolumn{5}{|l|}{ Formation of the theory } \\
\hline By establishing hypothesis & 22 & 34.37 & 2 & 6.45 \\
\hline Just through experiment and observation & 19 & 29.68 & 11 & 35.48 \\
\hline Through controlled experiment & 11 & 17.18 & 5 & 16.12 \\
\hline Scientific method & 10 & 15.62 & 10 & 32.25 \\
\hline Through thinking & 2 & 3.12 & 3 & 9.67 \\
\hline \multicolumn{5}{|l|}{ Law } \\
\hline Universalized information & 20 & 40 & 8 & 21.62 \\
\hline Theories accepted by everybody & 10 & 20 & 6 & 16.21 \\
\hline Researchable and provable information & 6 & 12 & 2 & 5.40 \\
\hline $\begin{array}{l}\text { Real information gained unchanged quality and } \\
\text { cannot be refuted }\end{array}$ & 5 & 10 & 8 & 21.62 \\
\hline $\begin{array}{l}\text { Hypothesis validated with observation and } \\
\text { experiments }\end{array}$ & 4 & 8 & 6 & 16.21 \\
\hline Facts proven with repeating experiments (shown) & 3 & 6 & 7 & 18.91 \\
\hline De facto information & 2 & 4 & 0 & 0 \\
\hline
\end{tabular}


Fatma Adak, Selda BAKIR - Çukurova Üniversitesi Eğitim Fakültesi Dergisi, 46(1), 2017, 134-164

\begin{tabular}{lrrrl}
\hline Formation of law & & & & \\
\hline Only controlled experiments and observations & 35 & 54.68 & 25 & 83.33 \\
Scientific methods & 29 & 45.31 & 5 & 16.66 \\
\hline The difference between theory and the law & & & & \\
\hline Theories can be transformed into law & 15 & 26.31 & 0 & 0 \\
Laws are universal, theories are not universal & 9 & 15.78 & 11 & 40.74 \\
Theories are unprovable facts & 8 & 14.03 & 2 & 7.40 \\
Don't Know & 8 & 14.03 & 0 & 0 \\
Laws do not change, theories may change & 5 & 8.77 & 0 & 0 \\
There are no differences between them & 4 & 7.01 & 0 & 0 \\
Law are certainly proven information, and theories & 4 & 7.01 & 3 & 11.11 \\
are greatly proven information & & & & \\
Laws are irrefutable information, theories are real & 2 & 3.50 & 8 & 29.62 \\
refutable information & & & & \\
Laws define event, theories define event & 0 & 0 & 3 & 11.11 \\
\hline
\end{tabular}

According to Table 7, opinions of both groups towards the definition of theory concentrate on "hypothesis proven with experiment and observation," "knowledge with its accuracy widely accepted" and "experiment results not accepted by everybody". Among other themes include answers such as "scientific facts," "experiment result considered by many scientists," "explanation of knowledge," "scientific proposition not yet proven" and "facts likely to be refuted". With regard to this sub-theme, it is difficult to say that all of pre-service teachers' and science teachers' opinions reflects non-traditional scientific approach. That is because answers by both participant groups are insufficient in literally reflecting non-traditional scientific approach. For example, "explanation of knowledge," "experiment results not accepted by everybody," "scientific proposition not yet proven" themes are insufficient for non-traditional scientific approach despite being sufficient for traditional opinion. With regard to the formation of theory, it has been observed that most of pre-service teachers' and teachers' opinions focus on themes such as "just experiment and observation," "establishing hypothesis," "controlled experiment".

With regard to law, pre-service teachers' and teachers' opinions mainly focus on "universalized information, real information that cannot be refuted, theories accepted by everybody," accordingly, it can be seen that scientific approach of both groups is against non-traditional scientific understanding or insufficient. With regard to formation of laws, pre-service teachers' and teacher' opinions are collected under themes of "only controlled experiments and observations" and "scientific method".

With regard to the difference between theory and law, most of teachers and pre-service teachers express that laws are universal and theories are not universal. Based on all these findings, it can be said that science teachers and pre-service science teachers have traditional understanding of science towards features of the nature of science including "scientific theories and laws". Below is the direct quote about this theme.

... "Dalton indicated that, in atom theory, atom cannot be broken. But later, it was proven with obtained information that atom could be broken (modern atomic theory). Laws are facts that cannot be change under no circumstances. Theories, on the other hand, are facts that can change..." (ST-13 [Traditional understanding of science])

Creative Nature of Scientific Knowledge/Social and Cultural Structure of Scientific Knowledge/Subjectivity. Findings about science teachers' and pre-service science teachers' opinions on features of the nature of science including "creative nature of scientific information," "social and cultural structure of scientific knowledge," and "subjectivity" are given in Table 8. 
Table 8.

Findings related to Themes of "Creative Nature of Scientific Knowledge," "Social and Cultural Structure of Scientific Knowledge" and "Subjectivity"

\begin{tabular}{|c|c|c|c|c|}
\hline \multirow[t]{2}{*}{ Sub-Themes } & \multirow{2}{*}{\multicolumn{2}{|c|}{$\begin{array}{l}\text { Pre-service Teacher } \\
\text { f\% }\end{array}$}} & \multicolumn{2}{|c|}{ Teacher } \\
\hline & & & $\mathrm{f}$ & $\%$ \\
\hline \multicolumn{5}{|c|}{ The Reason for Reaching Different Results by Scientists Despite Having Data } \\
\hline $\begin{array}{l}\text { Difference in personal opinions, ideas, perspectives, } \\
\text { special views and their difference in interpreting the } \\
\text { information }\end{array}$ & 25 & 49.01 & 19 & 63.33 \\
\hline Lacking precise information & 8 & 15.68 & 2 & 6.66 \\
\hline Imagination & 6 & 11.76 & 3 & 10 \\
\hline $\begin{array}{l}\text { Scientists' having different fields of study and } \\
\text { having different knowledge }\end{array}$ & 6 & 11.76 & 2 & 6.66 \\
\hline $\begin{array}{l}\text { They established different hypotheses based on } \\
\text { same data }\end{array}$ & 6 & 11.76 & 2 & 6.66 \\
\hline Selective perception & 0 & 0 & 2 & 6.66 \\
\hline \multicolumn{5}{|c|}{ The Difference between Scientific Knowledge and Scientific Thought } \\
\hline $\begin{array}{l}\text { Scientific knowledge is objective facts based on } \\
\text { experiment and observation, scientific thought is } \\
\text { subjective ideas }\end{array}$ & 22 & 41.50 & 10 & 38.46 \\
\hline $\begin{array}{l}\text { While the scientific knowledge is explained theories } \\
\text { and laws, scientific thought is explained with } \\
\text { emotions and beliefs }\end{array}$ & 15 & 28.30 & 8 & 30.76 \\
\hline $\begin{array}{l}\text { Scientific knowledge consists of proven facts, } \\
\text { scientific thoughts consists of the phase of producing } \\
\text { scientific knowledge based on imagination and } \\
\text { creativity }\end{array}$ & 8 & 15.09 & 5 & 19.23 \\
\hline Don't Know & 8 & 15.09 & 3 & 11.53 \\
\hline
\end{tabular}

According to Table 8, the reason for scientists' obtaining different results despite having same data is determined as the fact that nearly half of pre-service teachers and more than the half of teachers' opinions constitute of the theme, "difference in personal views, perspectives and subjective views". Answers such as "lack of precise information, imagination and establishing different hypotheses based on same data" are among notable themes.

With regard to the difference between scientific knowledge and scientific thought, it can be seen that teachers' pre-service teachers' opinions mostly focus on answers such as "Scientific knowledge is objective facts based on experiment and observation, scientific thought is subjective ideas" and "While the scientific knowledge is explained theories and laws, scientific thought is explained with emotions and beliefs", some teachers and pre-service teachers mention about imagination and creativity. Based on these findings, it can be said that science teachers and pre-service science teachers generally exhibit non-traditional understanding of science towards features of the nature of science including "creative nature of scientific knowledge," "social and cultural structure of scientific knowledge" and "subjectivity". Below is an example of a direct quote about this theme.

.... "Science stems from the fact that people look at events from their own perspectives. For example, when astronomers are those claiming the asteroid hit, natural scientists are those who say that the cause is volcanic eruption. In other words, they interpret data in accordance with their own fields..." (ST-13 [Non-traditional conception of science]) 


\section{Discussion \& Conclusion}

In the research, based on high level of pre-service science teachers' scores obtained from scientific epistemological beliefs scale, it can be said that pre-service science teachers have a traditional understanding of science. In the literature, there are some studies concluding that pre-service teachers' epistemological beliefs are towards traditional scientific understanding (Abd-El-Khalick \& BouJaoude, 1997; Abd-El-Khalick \& Akerson, 2004; Terzi, 2005; Meral \& Çolak, 2009; Ayvacı and Nas, 2010; Karabulut \& Ulucan, 2012). For instance; Meral and Çolak (2009), as a result of the study conducted with 651 students attending the teachers educational college, have determined that students have a traditional understanding of science. Karabulut and Ulucan (2012) have determined as a result of the study they conducted with the participation of the first and last grade pre-service physical education teachers that pre-service teachers have high level of traditional scientific beliefs.

Another finding of the study is that science teachers' scientific epistemological beliefs reflect traditional understanding of science. In the literature, there are some studies available in which teachers' epistemological beliefs are examined (Karhan, 2007; Doğan \& Abd-El-Khalick, 2008; Izgar \& Dilmaç, 2009; Kurt, 2010; Aslan \& Taşar, 2013; Bayır, 2016). Karhan (2007) has determined, in the study in which teachers' epistemological beliefs are examined, that teachers have superficial beliefs towards the fact that facts are single and absolute. Kurt (2010), as a result of the research conducted with 256 teachers, has determined that, while teachers' epistemological beliefs have sides suitable for partly developed epistemological understanding, they have more traditional understanding of science. Doğan and Abd-El-Khalick (2008) have revealed that, in addition to science teachers having traditional understanding of science towards the nature of science, they have similar opinions and these naive opinions independent of age, gender, geographic origin and social-economic status. Aslan and Taşar (2013), as a result of the study conducted with science teachers, have found that teachers have naive views about many sub-dimensions of the nature of science. Aslan (2009) indicates that naive opinion is the one that adopts positivist paradigm. Finding that science teachers are far from many sub-dimensions of the nature of science, Bayır (2016), based on the results of this study, claims that current findings do not support expectations of science education in the 21th century and reform movement in the country considering that the vision of 2004 and 2013 science programs was to raise students with science literacy.

Another result of this research is that there are no significant differences between science teachers' and pre-service science teachers' scientific epistemological beliefs. Analyzing the relationship between teachers' and pre-service teachers' epistemological beliefs, Alpan and Erdamar (2014), in their study conducted with 247 senior grade students attending Gazi University and 32 teachers guiding these students, have examined teachers' and pre-service teachers' epistemological beliefs before and after the teaching application and have observed that there are no significant differences between their epistemological beliefs before and after the implementation of the program. Saraç and Cappellaro (2015) have indicated that there are no significant differences among classroom teachers' and preservice teachers' opinions towards the nature of science apart from hierarchy of hypothesis-theory-law and consistency of inter-scientific concepts.

Science teachers' and pre-service science teachers' opinions towards the nature of science are determined according to features of the nature of science. It has been observed that both pre-service teachers' opinions and teachers' opinions towards "the source of scientific knowledge" focus mostly on experiment and observation. It is a true but incomplete information that, in obtaining scientific knowledge, scientific methods such as experiment and observation are used. This is one of myths accepted related the nature of science. Not only are there a single scientific method in obtaining scientific knowledge, but also are scientists' creativity and imagination important (Palmquist \& Finley, 1997; Abd-el-Khalick \& Akerson, 2004; Doğan, 2010). According to Doğan (2010), thinking that scientific knowledge is produced "through experiment" coincides with experimentalism knowledge theory, namely positivist view, that was supported by Francis Bacon and that suggests the only source of human knowledge as experimentalism. Accordingly, it can be said that science teachers and pre-service science 
teachers have a traditional understanding of science with regard to "the source of scientific knowledge". This finding shows similarities with many studies in the literature (Dickinson, Abd-El-Khalick \& Lederman, 2000; Abd-el-Khalick \& Akerson, 2004; Arı, 2010; Doğan, 2010; Dursun, 2015). For example, Abd-El-Khalick and Akerson (2004), as a result of their study conducted with 28 pre-service teachers attending science course, have determined that $86 \%$ of participants think that scientific knowledge is created through the scientific method constituting of single or serial phases; Doğan (2010) indicates that vast majority of high school students say that scientific knowledge is produced by scientific method.

It has been found that all science teachers and majority of pre-service teachers have opinions towards changeability of scientific knowledge with regard to features of the nature of science, "changeability of scientific knowledge". Very few of pre-service teachers' opinions are related to fact that information will not change. Accordingly, it can be said that pre-service teachers and science teachers have non-traditional conception of science with regard to features of the nature of science "changeability of scientific knowledge". This view is consistent with the results obtained from studies conducted by Lederman (1999), Doğan and Abd-el-Khalick (2008), Arı (2010) and Aslan (2009). For example, in a study conducted by Aslan (2009) with regard to volatility of scientific knowledge, Aslan has revealed that science and technology teachers hold the idea that scientific knowledge may change as a result of scientific studies repeated with new techniques and developed tools.

It can be said that, with regard to features of the nature of science including "nature of scientific knowledge is based on evidence and observation" and "observations, inferences and theoretical titles in science," science teachers and pre-service science teachers exhibit non-traditional conception of science. Although the study group consisted of high school students, Doğan (2010) also reached similar findings as a result of his study.

It has been determined that science teachers' and pre-service science teachers' opinions towards the whole theory focus on views such as "hypothesis proven with experiment and observation," "knowledge with its accuracy widely accepted" and "experiment results not accepted by everybody". With regard to definition of theory, it is difficult to say that all of pre-service teachers' and science teachers' opinions reflects non-traditional scientific approach. That is because answers by both participant groups are insufficient in literally reflecting non-traditional scientific approach. For example, "explanation of knowledge," "experiment results not accepted by everybody," "scientific proposition not yet proven" themes are insufficient for non-traditional scientific approach despite being sufficient for traditional opinion. With regard to law, it can be seen that pre-service teachers' and teachers' opinions mainly focus on themes such as universalized information, real information that cannot be refuted, theories accepted by everybody, and it can be seen that scientific approach of all is against nontraditional scientific understanding or insufficient. With regard to the difference between theory and law, most of teachers and pre-service teachers express that laws are universal and theories are not universal. Based on all findings obtained from participants' opinions towards theory, law, formation of theory and law and their differences, it can be said that science teachers and pre-service science teachers have traditional understanding of science towards the feature of nature of science, "scientific theories and laws". This finding coincides with the findings by Doğan (2010) and Mıhladız (2010) and Aslan (2009).One of the known myths towards the nature of science is the fact that hypotheses constitute theories, theories constitute laws (Aslan, 2009), namely, there is a hierarchy between theory and law (Dickinson, Abd-El-Khalick \& Lederman, 2000; Doğan Bora, Arslan \& Çakıroğlu, 2006). However, law and theories are different information types and they cannot be transformed into each other (Doğan, Çakıroğlu, Bilican \& Çavuş, 2009: 25). According to Irez (2008) and Doğan (2010), one of the biggest reasons for this error is wrong information in current course books.

It is observed that science teachers, pre-service science teachers and scientists may have different personal opinions, imagination etc., thus, different points of view; therefore, they mention about the view that they may achieve different outcomes and about features such as "creative nature of scientific knowledge, social and cultural structure and subjectivity". Based on these findings, it can be said that science teachers and pre-service science teachers, generally exhibit non-traditional understanding of 
science towards features of the nature of science including "creative nature of scientific knowledge," "social and cultural structure of scientific knowledge" and "subjectivity". Consistent with these findings, in Doğan's study (2010), students expressed that the reason for scientists producing different theories with regard to disappearance of the dinosaurs, different theories produced by people and inability to adopt a common theory despite same data at hand were different studies and different interpretations. In the study conducted by Aslan (2009), vast majority of science and technology teachers (66.2\%) expressed that "successful scientists should be always very open-minded, and they should also carry properties like imagination, intelligence and honesty."

In short, although, according to findings obtained from "Scientific Epistemological Scale," it was concluded that science teachers and pre-service science teachers have a traditional understanding of science; according to the findings obtained from "Opinions on Scientific Epistemological Beliefs Scale," it was revealed that both groups have traditional understanding of science based on positivist paradigm especially towards "nature of scientific knowledge to be based on experimentation, scientific theories and laws" features of the nature of science, and non-traditional (contemporary) scientific understanding based on post-positivist paradigm towards "the diversity of scientific knowledge, scientific knowledge to be based on proof and observation, observations, inferences and theoretical titles in science, creative nature of scientific knowledge, subjectivity and social and cultural structure of scientific knowledge". Abd-El Khalick and BouJaoude (1997) attribute science teachers' still having traditional conception of science to the fact that teachers training programs are not useful towards pre-service science teachers' developing information towards the nature of science that they need during their science education.

Based on the results of this research, science teachers may be provided with in-service trainings to guide them towards scientific understanding by saving them from traditional scientific understanding towards some features of the nature of science. Doğan, Çakıroğlu, Çavuş, Bilican and Arslan (2011) indicated that science and technology teachers' opinions towards the nature of science improved positively thanks to educational programs. Also, effective methods can be used towards the nature of science to develop pre-service science teachers' opinions on the nature of science. Although Abd-ElKhalick and Lederman (2000), as a result of wide literature review they applied, have indicated that attempts towards strengthening science teachers' opinions on the nature of science mainly fail, there are also studies indicating that some approaches are effective on this issue (Bianchini \& Colburn, 2000; Abd-El-Khalick, 2001; Köseoğlu, Tümay \& Budak, 2008; Türköz, 2015; Tola, 2016). For example, Abd-ElKhalick (2001) indicated that open reflective approach is effective in reflecting teachers' opinions about the nature of science. 


\section{Türkçe Sürümü}

\section{Giriş}

Epistemoloji, bilgiyle ilgili sorunları tenkit eden, bilginin nereden geldiğini, yapısını, kökenini,kriterlerini, geçerliliğini ve sınırlarını inceleyen felsefe alanı olarak ifade edilebilir (Hançerlioğlu, 1996; Yazıcı, 1999; Çüçen, 2001; Deryakulu, 2006; Cevizci, 2010). Felsefenin temel yapılarından biri olan epistemoloji, asıl olarak insan bilgisinin doğasını, bilginin kapsamını, kaynaklarını, sınırlarını, kavramsal bileşenlerini, doğruluğunu, geçerliğini tüm yönleriyle inceler. Epistemoloji üç temel soruyla ilişkilendirilebilecek araştırma alanlarını kapsamaktadır. Bu sorular; "Insan bilgisinin sınırları nelerdir?", "Insan bilgisinin kaynakları nelerdir?" ve "Insan bilgisinin doğası nedir?" şeklindedir (Muis, Bendixen \& Haerle, 2006). İnançsa bireylerin algılamalarını, anlamlandırmalarını ve bunlara yönelik tavrını oluşturan kabullenmeleridir (Deryakulu, 2006). Hofer ve Pintrich'e göre (1997), alınan bütün kesin yargıların ve sergilenen davranışların ardında, bireylerin sahip oldukları inançları yatmaktadır. Bireylerin sahip oldukları bilgi, bilme ve öğrenme ile ilgili inançları epistemolojik inanç olarak adlandırılır (Schommer, 1990; Deryakulu \& Büyüköztürk, 2005). Bilimsel epistemolojik inanç ise, bireylerin bilimin, bilimsel bilginin ne olduğu ve nasıl üretildiği ve paylaşıldığı ve nasıl öğretilmesi gerektiğiyle ilgili inançlarını kapsar (Deryakulu \& Bıkmaz. 2003).

Bilimsel bilginin oluşumuyla ilgili iki önemli paradigma bulunmaktadır. Pozitivist paradigmaya göre bilimsel bilginin oluşumunda, bilimsel deneyim fazlasıyla önemli olup, sadece ve sadece gözlemlenmiş ve kontrol edilmiş deneysel araştırmalar sonucunda elde edilen bilgiler güvenilirdir (Ekiz, 2009) ve bilimsel bilgiler tek ve mutlak doğrulardır (Özden, 2003). Oysa bilim, ne salt aklın ne de katıksız gözlem ve deneyin sonucudur (Yıldırım, 2014). Post-pozitivist paradigmaya göre ise bilimsel bilgi sadece deney, gözlem ve kullanılan yönteme bağlı değil, bilimin yapıldığı toplumun ve tarihin koşullarına da bağı olan bilgidir ve bilimsel doğrular ve yargılar mutlak değildir, değişebilir (Özden, 2003). Bilimsel epistemoljik inançlara dair çağdaş anlayış, öznelliği dikkate almayan, pozitivist paradigmaya dayanan geleneksel bilim anlayışından, bilim insanlarının yaşadıkları kültür ve toplumun etkisinde kaldığı, bireysel inanç ve değerlerin, hayal gücü ve sezgilerin de etkili olduğunu temel alan, post-pozitivist paradigmaya dayanan geleneksel olmayan bilim anlayışına doğru kaymıştır (Pomeroy, 1993).

Özellikle fen eğitimiyle ilgili yapılan çalışmalarda, epistemolojik görüş, epistemolojik inanç, bilimsel bilgi kavramlarının aynı anlamda kullanıldığı görülmektedir (Çoban \& Ergin, 2008). Bu terimlere ek olarak bilimin doğası da aynı amaçla kullanılmaktadır. Nitekim, Çoban ve Ergin'in (2008) çalışmalarında, bilimsel bilginin özelliğini anlatılırken, aslında bahsi geçen özelliklerin bilimin doğasının özellikleri olduğu görülmektedir. Aynı çalışmada bilimsel bilginin, "bilimsel bilginin doğasını, kaynağını, doğruluk değerini, sınırlarını ele alan tartışma" tanımı da bu savı desteklemektedir. Bu çalışmada epistemolojik inanç, bilimsel bilgi ve bilimin doğası aynı anlamda kullanılmıştır.

Khishfe ve Abd-El Khalick (2002), bilimin karmaşık, dinamik ve çoklu yapısından dolayı bilimin doğasının tanımının tam olarak yapılamadığını belirtseler de, Lederman (2007; akt. Akgün, 2015), bilimin doğasını, bilimin epistemolojisini yansıtan, bilgiyi oluşturma yolu ve bilimin üretilmesinde yer alan inançlar ve değerler bütünü olarak tanımlamaktadır. Bilimin doğasının (bilimsel bilginin) özellikleri şu başlıklar altında toplanabilir (Doğan, Çakıroğlu, Bilican \& Çavuş, 2009).

$\checkmark$ Bilimsel bilginin değişebilir doğası

$\checkmark$ Bilimsel bilginin deney ve gözlemlerden elde edilen kanıtlara dayanması

$\checkmark$ Öznellik

$\checkmark$ Bilimsel bilginin yaratıcı doğası

$\checkmark \quad$ Bilimsel bilginin sosyal ve kültürel yapısı

$\checkmark$ Gözlemler, çıkarımlar ve bilimde teorik başlıklar

$\checkmark$ Bilimsel teoriler ve kanunlar

Bireylerin bilimin doğasına nasıl baktıkları konusunun her geçen gün önem kazanması eğitim araştırmacılarının da ilgilerini çekmektedir.Bireysel farklılıklardan dolayı, bireylerin olay ve olgulara bakış 
açılarının farklı olması, her bireyin kendine özgü bir epistemolojisinin olduğuna (Evcim, 2010) ve bu inançların, öğrenme üzerinde önemli etkileri olduğuna dair çalışmalar bulunmaktadır (Hofer, 2001; Öngen, 2003; Deryakulu \& Büyüköztürk, 2005; Deryakulu, 2006; Eroğlu \& Güven, 2006). Örneğin, Deryakulu (2004), öğrenme sürecinde, gelişmiş epistemolojik inançlara sahip öğrencilerin, gelişmemiş epistemolojik inançlara sahip öğrencilere göre daha çok sayıda ve nitelikli öğrenme stratejilerini kullanmalarına bağlı olarak akademik yönden de daha başarılı oldukları sonucunu elde etmiştir. Yılmaz ve Delice (2007), problem çözmede yeterli bilgiye sahip olsalar dahi öğretmen adaylarının inançlarının, başarılarını olumsuz yönde etkilediğini iddia ederken, Izgar ve Dilmaç (2008) ve Gürol, Altunbaş ve Karaaslan (2010), özyeterlilik algısı yüksek öğretmenlerin epistemolojik inançlarının da yüksek olduğunu iddia etmektedirler. Schommer ve Walker (1997), üniversite öğrencilerinin okula yönelik tutumları ile epistemolojik inançlarını arasındaki ilişkiyi araştırdıkları çalışmalarında, öğrenme yeteneğinin doğumla geldiğine ve değiştirilemez bir yetenek olduğuna güçlü biçimde inanan öğrencilerin, öğrenme yeteneğinin geliştirilebileceğine inanan öğrencilere göre okuldan daha az hoşlandıklarını, eğitimin değerine daha az inandıklarını sonucuna ulaşmışlardır.Chan(2002),HongKongEğitimEnstitüsü’ndeki öğretmenadayları ile yaptığı çalışmada, öğrenmeninçabayavesürecebağlıolduğunainananöğretmen adaylarınınanlamlıöğrenmeleriiçinderinlemesineöğrenme

yaklaşımınıbenimsediklerini, diğertaraftanbilgininbirotoriteyadauzmantarafındansunulmasıgerektiğineina nanöğretmen adaylarının ise yüzeysel öğrenme yaklaşımınıbenimsedikleri sonucunubulmuştur. Ayrıca bilimsel epistemolojik inançların, kişilerin tercih ettikleri öğrenme-öğretme yaklaşımları, öğrenme stratejileri, bilgileri ve deneyimleri algılama ve yorumlama biçimleri üzerinde belirleyici bir etkisi bulunmaktadır (Deryakulu \& Bıkmaz, 2003).

Bilimsel okuryazar bireyler yetiştirmek, birçok ülkenin öğretim programlarının merkezinde yer almaktadır (Lederman, 1992; Abd-El-Khalick, 2001; Doğan, 2010; MEB, 2013; Akgün, 2015). En genel terimlerle bilimsel okur-yazar bir insan, kavramlar, teoriler, ilkeler, bilimsel süreçler ve bilim, teknoloji ve toplum arasındaki karmaşık ilişkilerle ilgili daha da önemlisi bilimin doğasına yönelik bir anlayış geliştirebilmelidir (Abd-El-Khalick \& BouJaoude, 1997). Hedef kitleyi yani bilim okur-yazarı olarak yetişmesi beklenen öğrencileri yetiştirecek olan öğretmenlerin bilimsel bilginin doğasına (bilimsel epistemolojik inanç) yönelik görüşlerinin belirlenmesi öğretim programlarının işlevselliği açısından önem kazanmaktadır. İlgili literatür incelendiğinde, öğretmen adaylarının epistemolojik inançları ile birçok çalışma (Öngen, 2003; Deryakulu \& Büyüköztürk, 2005; Terzi, 2005; Eroğlu \& Güven, 2006; Yılmaz \& Delice, 2007; Ayaz, 2009; Meral \& Çolak, 2009; Öztürk, 2009; Öztürk, 2011) varken öğretmenlerin epistemolojik inançları üzerindeki araştırmaların (Izgar \& Dilmaç, 2008; Ayvacı \& Nas, 2010; Akçay, 2011) sayısının daha sınırlı sayıda olduğu tespit edilmiştir. Bu bakımdan araştırmanın örneklemi, fen bilgisi öğretmen adayları ve fen bilimleri öğretmenleri olarak belirlenmiştir. Fen bilimleri öğretmenlerinin ve fen bilgisi öğretmen adaylarının bilimsel epistemolojik inançlarını ve bilimin doğasına dair görüşlerini belirlemek için yapılan bu çalışmada aşağıdaki sorulara cevap aranmıştır:

1.Fen bilgisi öğretmen adaylarının bilimsel epistemolojik inançları ne düzeydedir?

2.Fen bilimleri öğretmenlerinin bilimsel epistemolojik inançları ne düzeydedir?

3.Fen bilgisi öğretmen adayları ile fen bilimleri öğretmenlerinin bilimsel epistemolojik inançları arasında anlamlı bir fark var mıdır?

4.Fen bilimleri öğretmenlerinin ve fen bilgisi öğretmen adaylarının bilimin doğası hakkındaki görüşleri nelerdir?

\section{Yöntem}

Bu çalışmada karma araştırma deseni esas alınmıştır. Karma araştırma, nicel ve nitel verilerin veya tekniklerin birleştirildiği araştırma desenidir (Christensen, Johnson \& Turner, 2015). Mevcut çalışma da verilerin nicel ve nitel olması açısından karma araştırmadır. Araştırmada nicel veriler tarama modeliyle, nitel veriler ise olgubilim incelemesiyle toplanmıştır. Araştırmada geçerlik ve güvenirliği sağlamak için karma araştırmalarda geçerli bazı önlemler alınmıştır. Bunlardan birincisi araştırmacının bir yöntemin zayıflığını kapatmak için başka bir yöntemi kullanmasına dayanan, zayıflıkları indirme geçerliğidir 
(Christensen, Johnson \& Turner, 2015). Nicel verilerin eksikliği olan derinlemesine bilgi, nitel yollarla elde edilmiştir. İkincisi ise araştırmacının uygun nicel, nitel ve karma yönteminin kendilerine has geçerliklerini karşılaştırmasına dayanan çoklu geçerliktir (Christensen, Johnson \& Turner, 2015). Nitel veriler için alınan tedbirlerden bir diğeri de çeşitleme (triangulation) dir. Çeşitleme, veri kaynakları, yöntem ve araştırmacı çeşitlemesi olarak üç şekilde olabilir (Patton, 2014). Bu çalışma için veri kaynakları, araştırmacı çeşitlemesi ve yöntem çeşitlemesi kullanılmıştır. Veri kaynağı olarak, fen bilimleri öğretmenleri ve fen bilgisi öğretmen adayları seçilmiştir. Katılımcıların kendi aralarında da çeşitli olması açısından öğretmenler hem il merkezindeki okullardan hem de merkez ilçelerden seçilmiş, öğretmen adayları ise fen bilgisi öğretmenliği anabilim dalının 1.2.3 ve 4. sınıflarından seçilmiştir. Yöntem çeşitliliği için tarama ve olgubilim desenleri kullanılmıştır. Araştırmacı çeşitliliği açısından da çalışmayı iki araştırmacı yürütmüştür. Böylelikle araştırmacıların öznel yargılarının mümkün olduğu kadar önüne geçilmeye çalışılmıştır.

\section{Katılımcılar ve Veri Toplama Süreci}

Araştırmanın çalışma grubu,Burdur il merkezi ve ilçe merkezlerindeki ortaokullarda görev yapan 61 fen bilimleri öğretmeni ve 2013-2014 eğitim-öğretim yılında bir üniversitenin eğitim fakültesi Fen Bilgisi Öğretmenliği Anabilim Dalı 1.. 2.. 3. ve 4. sınıfında öğrenim görmekte olan ve oranlı tabakalı amaçsal örnekleme yoluyla seçilen 236 fen bilgisi öğretmen adayından oluşmaktadır. Büyüköztürk, Çakmak, Akgün, Karadeniz ve Demirel'e göre (2009:91). "Tabakalı örneklemeden, örneklem için birim seçmede seçkisizliğin dikkate alınmaması nedeniyle farklılaşan tabakalı amaçlı örnekleme,literatürde kota örnekleme olarak da bilinir". Öğretmen adayları için bu örnekleme yönteminin seçilme sebebi, her sınıf düzeyinden öğretmen adayının örneklemde bulunmasının daha uygun olacağının düşünülmesidir. Bu iki grubun tamamına nicel verilen toplandığı "BilimselEpistemolojik Inançlar Ölçeği” uygulanmıştır.Nitel verilerinin toplandığı "Bilimsel Epistemoloji Üzerine Görüşler Anketi” ise çalışmanın örnekleminden rastgele seçilen 85 fen bilgisi öğretmen adayına ve 40 fen bilimleri öğretmenine uygulanmış, ancak fen bilgisi öğretmen adaylarından $28^{\prime} i$ ve fen bilimleri öğretmenlerinden 10 tanesi, ölçeklerin tamamını doldurmamaları nedeniyle araştırmadan çıkarılmıştır. Son durumda, nitel veriler 57 fen bilgisi öğretmen adayı ve 30 fen bilimleri öğretmeninden toplanmıştır.

\section{Kullanılan Veri Toplama Araçları}

Bilimsel Epistemolojik İnanç Ölçeği. BilimselEpistemolojik İnançlar Ölçeği,Pomeroy (1993) tarafından geliştirmiştir. Özgün formu İngilizce olan bu ölçek üç alt boyut altında toplam 50 maddeden oluşmaktadır. Deryakulu ve Bıkmaz (2003) tarafından Türkçeye çevrilen ölçek, geçerlik ve güvenirlik analizleri sonucunda, geleneksel bilim anlayışını yansıtan 22 olumlu madde ve geleneksel olmayan bilim anlayışını yansıtan 8 olumsuz madde olmak üzere, toplam 30 maddeden oluşmaktadır. Ölçeğin Türkçe'ye çevrilmiş orijinal formu için hesaplanan alfa iç tutarlılık katsayısı.91'dir (Deryakulu ve Bıkmaz, 2003). Ölçek (1) Kesinlikle Katılmıyorum ile (5) Kesinlikle Katılıyorum arasında değişen likert tipi beşli derecelendirmeye sahiptir. Ölçekten alınacak en düşük puan 1, en yüksek puan ise 5'tir. Ölçekten alınan yüksek puan (>2.5) geleneksel bilim anlayışına, düşük puan (<2.5) ise geleneksel olmayan (çağdaş) bilim anlayışına güçlü inancı göstermektedir.

Bilimsel Epistemoloji Üzerine Görüşler Ölçeği. Bilimsel Epistemoloji Üzerine Görüşler Anketi,Abd-ElKhalick (2002) tarafından geliştirilmiştir. Bu anket 10 açık uçlu sorudan oluşmaktadır. Anket, Doğan (2010) tarafından adapte edilmiş ve içerik geçerliği için iki uzmanın görüşleri alınmıştır. Özgün formu 10 sorudan oluşan ölçeğin 8 sorusu bu çalışma için kullanılmıştır. Sorular bilimin doğasının;

- Bilimsel Bilginin Değişebilir Doğası

- Bilimsel Bilginin Doğası Kanıta ve Gözleme Dayalıdır

- Öznellik

- Bilimsel Bilginin Yaratıcı Doğası

- Bilimsel Bilginin Sosyal ve Kültürel Yapısı

- Bilimsel Teoriler ve Kanunlar 
- Gözlemler Çıkarımlar ve Bilimde Teorik Başlıklar (Kanıt ve Veri),özelliklerini kapsamaktadır.

\section{Veri Analizi}

Araştırmanın nicel verilerini oluşturan bilimsel epistemolojik inanç ölçeğinin analizlerinde, öğretmen adaylarının ve öğretmenlerin puanlarının normal dağılımlarına bakılarak, betimsel analiz ve ilişkisiz örneklemler için tek faktörlü varyans analizi (One-Way ANOVA) yapılmıştır. Araştırmanın nicel verilerini oluşturan "Bilimsel Epistemolojik İnanç Ölçeği”nden alınan puanların analizi için, ölçekteki tüm maddelerden alınan toplam puanlar kullanılmıştır. Nicel verilerin elde edildiği ölçeğin bu çalışma için Cronbach Alfa güvenirlik katsayısı .91 olarak hesaplanmıştır. Araştırmanın nitel verileri, katılımcıların “Bilimsel Epistemolojik İnançlar Üzerine Görüşler Anketi”ne verdikleri cevaplardan elde edilmiştir. Nitel veriler, nitel analiz yöntemlerinden içerik analizi ile yapılmıştır. İçerik analizinde veriler derinlemesine bir incelemeye tabi tutulur, birbirine benzer olan veriler belli temalar ve kavramlar çerçevesinde birleştirilir (Yıldırım \& Şimşek, 2008). Bu bağlamda araştırmacılar tarafından defalarca okunan anketler içerik analizine tabi tutulmuş, birbirine benzeyen veriler kodlanmış ve bu kodları ifade edecek temalar oluşturulmuştur. Araştırmada verilerin analizinde güvenirliğin ve tutarlığın sağlanması açısından aynı veri seti araştırmacıların her ikisi tarafından kodlanmış ve kodlayıcılar arası tutarlılığa bakılmıştır. Tutarlılık, “Görüş birliği/(Görüş birliği+Görüş ayrılığı) x 100” formülü kullanılarak hesaplanmıştır (Miles \& Huberman, 1994). Bu hesaplama sonucunda araştırmacıların analiz sonuçları arasında, .87 oranında tutarlılık tespit edilmiştir. Ayrıca, nitel verilerde dış geçerlilik için doğrudan alıntılar kullanılmıştır.

\section{Sonuçlar}

\section{Birinci Alt Probleme iliş̧kin Bulgular}

Fen bilgisi öğretmen adaylarının "Bilimsel Epistemolojik İnanç Ölçeği”nden aldıkları puanların betimsel analiz sonuçları Tablo 1'de sunulmuştur.

Tablo 1.

Fen Bilgisi Öğretmen Adaylarının Bilimsel Epistemolojik Inanç Puanlarının Betimsel Analiz Sonuçları

\begin{tabular}{llllll}
\hline Değişken & $\mathrm{N}$ & Min & Max & $\overline{\mathrm{X}}$ & SS \\
\hline $\begin{array}{l}\text { Bilimsel Epistemolojik } \\
\text { inanç }\end{array}$ & 236 & 2.97 & 3.93 & 3.48 & .197 \\
\hline
\end{tabular}

Tablo 1'de görüldüğü gibi, fen bilgisi öğretmen adaylarının "Bilimsel Epistemolojik İnanç Ölçeği” ortalama puanının (X=3.48. SS=.197) yüksek olmasına dayalı olarak, fen bilgisi öğretmen adaylarının geleneksel bilimsel anlayışa sahip oldukları söylenebilir.

\section{İkinci Alt Probleme iliş̧kin Bulgular}

Fen bilimleri öğretmenlerinin bilimsel epistemolojik inanç düzeylerini belirlemek için yapılan betimsel analiz sonuçları Tablo 2'de sunulmuştur.

Tablo 2.

Fen Bilimleri Öğretmenlerinin Bilimsel Epistemolojik Inanç Puanlarının Betimsel Analiz Sonuçları

\begin{tabular}{llllll}
\hline Değişken & $\mathrm{N}$ & Min & Max & $\overline{\mathrm{X}}$ & SS \\
\hline Bilimsel & 61 & 2.83 & 4.00 & 3.50 & .22 \\
Epistemolojik İnanç & & & & & \\
\hline
\end{tabular}


Tablo 2 incelendiğinde, "Bilimsel Epistemolojik İnanç Ölçeği” ortalama puanlarının (X=3.50. SS=.22) yüksek olmasına dayalı olarak, fen bilimleri öğretmenlerinin geleneksel bilimsel anlayışa sahip oldukları söylenebilir.

\section{Üçüncü Alt Probleme ilişkin Bulgular}

Fen bilimleri öğretmenlerinin ve fen bilgisi öğretmen adaylarının bilimsel epistemolojik inanç düzeyleri arasındaki farkı incelemek için yapılan One-Way ANOVA sonuçları Tablo 3’te verilmiştir.

Tablo 3.

Fen Bilimleri Öğretmenlerinin ve Fen Bilgisi Öğretmen Adaylarının Bilimsel Epistemolojik Inançlarının One-Way ANOVA Testi Sonuçları

\begin{tabular}{llllll}
\hline $\begin{array}{l}\text { Varyansın } \\
\text { Kaynağı }\end{array}$ & $\begin{array}{l}\text { Kareler } \\
\text { toplamı }\end{array}$ & Sd & Kareler ortalaması & $\mathrm{F}$ & $\mathrm{P}$ \\
\hline Gruplararası & .024 & 1 & .024 & .594 & $.442^{*}$ \\
Gruplariçi (hata) & 12.089 & 295 & .041 & & \\
Toplam & 12.114 & 296 & & \\
\hline
\end{tabular}

* $\mathrm{p}>.05$

Tablo 3'te görüldüğü gibi, yapılan varyans analizi sonucunda, fen bilimleri öğretmenlerinin bilimsel epistemolojik inanç puanları ( $X=3.47 . S S=.19)$ ile fen bilgisi öğretmen adaylarının bilimsel epistemolojik inanç puanları (X=3.50. $S S=.22)$ arasında anlamlı bir fark bulunmamıştır $\left(F_{1-295}=0.594 ; p>.05\right)$.

\section{Dördüncü Alt Probleme İlişkin Bulgular}

Bu kısımdaki bulgular, bilimin doğasının özellikleriyle ilişkilendirilerek oluşturulan temalarla alt başlıklar halinde verilmiştir.

Bilimsel Bilginin Kaynağı. Bilimsel bilginin kaynağına yönelik, katılımcıların görüşlerinden elde edilen verilerin analizi sonucunda ulaşılan bulgular Tablo 4'te verilmiştir.

\section{Tablo 4.}

"Bilimsel Bilginin Kaynağı" Temasına İlişkin Bulgular

\begin{tabular}{|c|c|c|c|c|}
\hline \multirow[t]{2}{*}{ Alt Temalar } & \multicolumn{2}{|c|}{ Öğretmen Adayı } & \multicolumn{2}{|c|}{ Öğretmen } \\
\hline & $\mathrm{f}$ & $\%$ & $\mathrm{f}$ & $\%$ \\
\hline Sadece deney ve gözlem & 19 & 33.92 & 8 & 28.57 \\
\hline Tesadüfen & 13 & 23.21 & 3 & 10.71 \\
\hline Bilimsel yöntem & 6 & 10.71 & 6 & 21.42 \\
\hline Araştırma ve inceleme & 6 & 10.71 & 0 & 0 \\
\hline Merak & 4 & 7.14 & 3 & 10.71 \\
\hline İhtiyaçlardan yola çıkarak & 3 & 5.35 & 4 & 14.28 \\
\hline Deneme yanılma & 3 & 5.35 & 0 & 0 \\
\hline Düşünme & 2 & 3.57 & 2 & 7.14 \\
\hline Teknoloji & 0 & 0 & 2 & 7 \\
\hline
\end{tabular}

Tablo 4'e göre, hem öğretmen adaylarının hem de öğretmen görüşlerinin en fazla "sadece deney ve gözlem"de yoğunlaştığı görülmüştür. Öğretmen adayı görüşlerinden sadece deney ve gözlemi,sırasıyla.tesadüfen, bilimsel yöntem, araştırma ve inceleme, merak, ihtiyaçlar ve deneme- 
yanılma temaları izlerken, öğretmen görüşlerinin de benzer temalar etrafında toplandığı görülmekle beraber, sadece deney ve gözlemden sonra en fazla "bilimsel yöntem" görüşünün hakim olduğu ve öğretmen adaylarının hiç değinmediği "teknoloji” temasına değindikleri dikkati çekmektedir. Ayrıca, bilimsel bilginin üretilmesinde deneyin kullanıldığını söyleyen öğretmenlerin ve öğretmen adaylarının büyük çoğunluğu "Çiçeğinizi yetiştirirken bilimsel yolları kullanmadan daha hızlı büyütecek mucize bir sıvıyı kullanır mısınız?' sorusuna "Böyle bir şeyi denemeyeceklerini” söylemişlerdir. Bu bulgulara göre fen bilimleri öğretmenlerinin ve öğretmen adaylarının bilimsel bilginin kaynağına yönelik, geleneksel bilim anlayışına sahip oldukları söylenebilir. Bu temayla ilgili doğrudan alıntı örneği aşağıda verilmiştir.

"Bu mucizevi sıvı market reyonlarına gelmeden önce kontrollü deneylerle test edilmiştir. Bundan dolayı benim denememe gerek yoktur. Zaten işe yarayacaktır"...(FÖA-41 [Geleneksel bilim anlayışı].

Bilimsel Bilginin Değişebilirliği. Fen bilimleri öğretmen ve öğretmen adaylarının, bilimin doğasının "bilimsel bilginin değişebilirliği” özelliğine yönelik görüşleriyle ilgili bulgular Tablo 5'te görülmektedir.

Tablo 5.

"Bilimsel Bilginin Değişebilirliği" Teması Ile ilgili Bulgular

\begin{tabular}{lllll}
\hline Alt Temalar & \multicolumn{2}{l}{ Öğretmen adayı } & \multicolumn{2}{l}{ Öğretmen } \\
& $f$ & $\%$ & 8 & 28.57 \\
\hline Teknolojik gelişmelerle değişir & 17 & 32.69 & 7 & 25 \\
Bilimin ilerlemesiyle değişir & 12 & 23.07 & 2 & 7.14 \\
Araştırma ve deneyle değişir & 7 & 13.46 & 4 & 14.28 \\
Yeni düşünce ve yorumla değişir & 6 & 11.53 & 5 & 17.85 \\
Teoriler değişir & 4 & 7.69 & 0 & 0 \\
Kanunlar değişmez & 3 & 5.76 & 0 & 0 \\
Bilgiler değişmez & 2 & 3.84 & 2 & 7.14 \\
Çağın gereksinimleri ile değişir & 1 & 1.92 & & 7 \\
\hline
\end{tabular}

Tablo 5 incelendiğinde, öğretmen adaylarının görüşlerinin çok azının kanunların, bilgilerin değişmeyeceği yönünde iken, öğretmen görüşlerinin tamamının öğretmen adaylarının görüşlerinin ise büyük çoğunluğunun bilimsel bilginin, bilimin ilerlemesi, teknolojik gelişmeler, teoriler, yeni düşünce ve yorumlar, araştırma ve deneyler veya çağın gereksinimleriyle değişebileceği yönünde olduğu görülmektedir. Buna göre öğretmen adaylarının ve fen bilimleri öğretmenlerinin bilimin doğasının "bilimsel bilginin değişebilirliği" özelliğiyle ilgili olarak geleneksel olmayan bilimsel anlayışa sahip oldukları söylenebilir. Bu temayla ilgili doğrudan alıntı örnekleri aşağıda verilmiştir.

..."Bilim ve bilgi durağan değildir araştırma ve teknolojik gelişmelerle birlikte bilgi de değişim göstermektedir..." (FÖ-29 [Geleneksel olmayan bilim anlayışı])

... "Bilimsel yeni üretilen fikirler ve ortaya atılan hipotezler doğrultusunda değişebilir. Sabit değildir..." (FÖA-37 [Geleneksel olmayan bilim anlayışı])

Bilimsel Bilginin Doğası Kanıta ve Gözleme Dayalıdır/ Gözlemler. Çıkarımlar ve Bilimde Teorik Başlıklar. Fen bilimleri öğretmen ve fen bilgisi öğretmen adaylarının, bilimin doğasının "bilimsel bilginin doğası kanıta ve gözleme dayalıdır" ve "gözlemler, çıkarımlar ve bilimde teorik başlıklar" özelliklerine yönelik görüşlerine ilişkin bulgular Tablo 6’da görülmektedir. 
Tablo 6.

"Bilimsel Bilginin Doğası Kanıta Ve Gözleme Dayalıdır" ve "Gözlemler, Çıkarımlar Ve Bilimde Teorik Başlıklar" Temasına ilişkin Bulgular

\begin{tabular}{|c|c|c|c|c|}
\hline \multirow[t]{2}{*}{ Alt Temalar } & \multicolumn{2}{|c|}{ Öğretmen adayı } & \multicolumn{2}{|c|}{ Öğretmen } \\
\hline & \multicolumn{2}{|c|}{ f $\%$} & \multicolumn{2}{|c|}{$\%$} \\
\hline \multicolumn{5}{|l|}{ Kanit } \\
\hline Delil & 19 & 38 & 16 & 59.25 \\
\hline İpucu, iz & 9 & 18 & 3 & 11.11 \\
\hline Deney ve gözleme dayılı bilgi & 7 & 14 & 4 & 14.81 \\
\hline Gerçeğin ispatı & 6 & 12 & 0 & 0 \\
\hline Önermeler & 5 & 10 & 4 & 14.81 \\
\hline Araştırmanın temeli & 4 & 8 & 0 & 0 \\
\hline \multicolumn{5}{|l|}{ Veri } \\
\hline Bilgi toplamak & 23 & 45.09 & 5 & 19.23 \\
\hline Nitel ve nicel bilgiler & 10 & 19.60 & 14 & 53.84 \\
\hline Araştırmanın temelini oluşturan ana öğe & 7 & 13.72 & 2 & 7.69 \\
\hline Araştırma sonundaki değerler & 5 & 9.80 & 1 & 3.84 \\
\hline Yazılı materyaller & 3 & 5.88 & 0 & 0 \\
\hline Bilginin basamaklara bölünmüş hali & 3 & 5.88 & 0 & 0 \\
\hline Bilginin ham hali & 0 & 0 & 4 & 15.38 \\
\hline \multicolumn{5}{|l|}{ Data ve kanıtların toplanma yolları } \\
\hline Gözlem & 13 & 22.41 & 7 & 20.58 \\
\hline Anket & 10 & 17.24 & 4 & 11.76 \\
\hline Araştırma / İnceleme & 8 & 14.54 & 2 & 5.88 \\
\hline Deney / Kontrollü deney & 7 & 12.06 & 5 & 14.70 \\
\hline Görüşme / mülakat & 6 & 10.34 & 2 & 5.88 \\
\hline Gezi/ Gözlem & 4 & 6.89 & 3 & 8.82 \\
\hline Eser incelemesi & 3 & 5.17 & 5 & 14.70 \\
\hline Arşiv araştırması & 3 & 5.17 & 2 & 5.88 \\
\hline Bilimsel yöntemler & 2 & 3.44 & 1 & 2.94 \\
\hline Internet & 2 & 3.44 & 2 & 5.88 \\
\hline Doğa araştırması & 0 & 0 & 1 & 2.94 \\
\hline
\end{tabular}

Tablo 6 incelendiğinde, kanıt kelimesiyle ilgili öğretmen adaylarının görüşleri sırasıyla delil, ipucu ve iz, deney ve gözleme dayalı bilgi, gerçeğin ispatı, önerme ve araştırmanın temeli temalarında yoğunlaşırken, öğretmen görüşlerinin ise gerçeğin ispatı ve araştırmanın temeli temaları haricinde benzer temalarda yoğunlaştığı saptanmıştır. Ayrıca, öğretmenlerin çoğunun kanıtı, "delil” olarak gördükleri belirlenmiştir. Öğretmen ve öğretmen adaylarının veriye yönelik görüşlerinin ise, nitel ve nicel bilgi, bilgi toplamak, bilginin ham hali, araştırma sonundaki değerler, araştırmanın temelini oluşturan ana öğe temaları üzerinde yoğunlaştıkları görülmüştür. Bu alt temalara ilave olarak öğretmen adaylarının görüşlerinden sayısı az da olsa yazılı materyaller ve bilginin basamaklara bölünmüş hali temaları da ortaya çıkmıştır. Öğretmen adayları veriyi en çok "bilgi toplamak" olarak tanımlarken, öğretmenler en çok "nitel ve nicel bilgiler" olarak tanımlamaktadırlar. Data ve kanıtların toplanma yollarına dair öğretmen adaylarının verdikleri cevapların büyük çoğunluğunun gözlem, anket, araştırma/ inceleme, deney/kontrollü deney ve görüşme/mülakat olduğu görülürken, öğretmen görüşlerinin büyük çoğunluğunun ise gözlem, deney/kontrollü deney, eser incelemesi ve ankette yoğunlaştığı görülmektedir. Tüm bu bulgulara dayanarak, fen bilimleri öğretmen ve fen bilgisi öğretmen adaylarının. bilimin doğasının "bilimsel bilginin doğası kanıta ve gözleme dayalıdır" ve "gözlemler, çıkarımlar ve bilimde teorik başlıklar" özelliklerine yönelik geleneksel olmayan bilim anlayışını sergiledikleri söylenebilir. Aşağıda bu temayla ilgili doğrudan alıntı örnekleri verilmiştir. 
... "Kanıt.bir problemin çözümünde etraftan topladığımız ve hipotezleri doğrulayacak bilgilerdir..."(FÖ8 [ Geleneksel olmayan bilim anlayışı])

... "Deney ve gözlemler sonucu elde edilen nicel ve nitel bilgilere veri denir..."(FÖ-9 [ Geleneksel olmayan bilim anlayışı])

Bilimsel Teoriler ve Kanunlar. Fen bilimleri öğretmen ve fen bilgisi öğretmen adaylarının bilimin doğasının "bilimsel teoriler ve kanunlar" özelliğine yönelik görüşlerine ilişkin bulgular Tablo 7'de verilmiştir.

Tablo 7.

"Bilimsel Teoriler ve Kanunlar" Teması

\begin{tabular}{|c|c|c|c|c|}
\hline \multirow[t]{2}{*}{ Alt Temalar } & \multirow{2}{*}{\multicolumn{2}{|c|}{$\begin{array}{l}\text { Öğretmen adayı } \\
\mathrm{f} \%\end{array}$}} & \multicolumn{2}{|c|}{ Öğretmen } \\
\hline & & & & $\%$ \\
\hline \multicolumn{5}{|l|}{ Teori } \\
\hline Doğruluğu büyük ölçüde kabul edilmiş bilgi & 11 & 17.18 & 10 & 23.25 \\
\hline Deney ve gözlemle ispatlanmış hipotez & 10 & 15.62 & 15 & 34.88 \\
\hline $\begin{array}{l}\text { Herkes tarafından kabul görmemiş deney } \\
\text { sonucu }\end{array}$ & 9 & 14.06 & 5 & 11.62 \\
\hline Çürütülme olasılığı olan gerçekler & 8 & 12.05 & 2 & 4.65 \\
\hline $\begin{array}{l}\text { Birçok bilim insanı tarafından kabul görmüş } \\
\text { deney sonucu }\end{array}$ & 7 & 10.93 & 3 & 6.97 \\
\hline $\begin{array}{l}\text { Doğruluğu kabul edilmiş ancak yanlışlanabilme } \\
\text { olasılığı olan hipotezler }\end{array}$ & 6 & 9.37 & 4 & 9.30 \\
\hline Henüz kanıtlanmamış bilimsel önerme & 5 & 7.81 & 1 & 2.32 \\
\hline Bilimsel gerçekler & 3 & 4.68 & 3 & 6.97 \\
\hline Bilginin açıklaması & 3 & 4.68 & 0 & 0 \\
\hline Kanıtlanması zor görüş & 2 & 3.12 & 0 & 0 \\
\hline \multicolumn{5}{|l|}{ Teorinin oluşumu } \\
\hline Hipotez kurarak & 22 & 34.37 & 2 & 6.45 \\
\hline Sadece deney ve gözlemle & 19 & 29.68 & 11 & 35.48 \\
\hline Kontrollü deneyle & 11 & 17.18 & 5 & 16.12 \\
\hline Bilimsel yöntem & 10 & 15.62 & 10 & 32.25 \\
\hline Düşünerek & 2 & 3.12 & 3 & 9.67 \\
\hline \multicolumn{5}{|l|}{ Kanun } \\
\hline Evrenselleşmiş bilgi & 20 & 40 & 8 & 21.62 \\
\hline Herkes tarafından kabul edilmiş teorilerdir & 10 & 20 & 6 & 16.21 \\
\hline Araştırılabilir ve kanıtlanabilir bilgi & 6 & 12 & 2 & 5.40 \\
\hline $\begin{array}{l}\text { Değişmez nitelik kazanmış ve çürütülemeyen } \\
\text { gerçek bilgiler }\end{array}$ & 5 & 10 & 8 & 21.62 \\
\hline $\begin{array}{l}\text { Hipotezlerin gözlem ve deneylerle doğrulanmış } \\
\text { hali }\end{array}$ & 4 & 8 & 6 & 16.21 \\
\hline $\begin{array}{l}\text { Tekrarlanan deneylerle doğruluğu ispatlanmış } \\
\text { (kanıtlanmış) gerçekler }\end{array}$ & 3 & 6 & 7 & 18.91 \\
\hline Genel geçer bilgi & 2 & 4 & 0 & 0 \\
\hline \multicolumn{5}{|l|}{ Kanunun oluşumu } \\
\hline Sadece kontrollü deneyler ve gözlemler & 35 & 54.68 & 25 & 83.33 \\
\hline Bilimsel yöntemler & 29 & 45.31 & 5 & 16.66 \\
\hline \multicolumn{5}{|l|}{ Teori ve kanun arasındaki fark } \\
\hline Teoriler kanuna dönüşebilir & 15 & 26.31 & 0 & 0 \\
\hline Kanunlara evrenseldir, teoriler evrensel değildir & 9 & 15.78 & 11 & 40.74 \\
\hline Teoriler ispatlanamaz gerçeklerdir & 8 & 14.03 & 2 & 7.40 \\
\hline
\end{tabular}


Bilmiyorum

Kanunlar değiş̧mez teoriler değişebilir

Aralarında fark yoktur

Kanunlar kesin olarak kanıtlanmış bilgiler, teoriler ise büyük ölçüde kanıtlanmış bilgilerdir Kanunlar, çürütülemez gerçek bilgi,teoriler çürütülebilir gerçek bilgilerdir

Kanunlar olayı tanımlar, teoriler olayı açıklar

\begin{tabular}{llll}
8 & 14.03 & 0 & 0 \\
5 & 8.77 & 0 & 0 \\
4 & 7.01 & 0 & 0 \\
4 & 7.01 & 3 & 11.11 \\
& & & \\
2 & 3.50 & 8 & 29.62 \\
0 & 0 & 3 & 11.11 \\
\hline
\end{tabular}

Tablo 7’ye göre,teorinin tanımına yönelik her iki grubun görüşlerinin de en fazla, “deney ve gözlemle ispatlanmış hipotez", "doğruluğu büyük ölçüde kabul edilmiş bilgi”, "herkes tarafından kabul görmemiş deney sonucu"nda yoğunlaştıkları görülmektedir. "Bilimsel gerçekler", birçok bilim insanı tarafından kabul görmüş deney sonucu", "bilginin açıklanması", "henüz kanıtlanmamış bilimsel önerme" gibi cevapların yanında "çürütülme olasılığı olan gerçekler" cevabı da belirlenen diğer temalar içindedir. Bu alt temayla ilgili olarak, öğretmen adayları ve öğretmen görüşlerinden tamamının geleneksel olmayan bilimsel anlayışı yansıttığını söylemek güçtür. Çünkü her iki katılımcı grubun verdikleri cevaplar, tam anlamıyla geleneksel olmayan bilimsel anlayışı yansıtmakta yetersiz kalmaktadır. Örneğin "bilginin açıklanması", "herkes tarafından kabul görmemiş deney sonucu", henüz kanıtlanmamış bilimsel önerme" temaları her ne kadar geleneksel görüş olmasa da geleneksel olmayan bilimsel anlayış için de yetersiz kalmaktadır. Teorinin oluşumuyla ilgili olarak, öğretmen adaylarının ve öğretmenlerin görüşlerinin çoğunun geleneksel olmayan bilimsel anlayış için yetersiz kabul edilebilecek "sadece deney ve gözlem", "hipotez kurmak", "kontrollü deney" gibi temalarda yoğunlaştıkları görülmüştür.

Kanunla ilgili olarak ise öğretmen adaylarının ve öğretmenlerin görüşlerinin çoğunlukla, "evrenselleşmiş bilgi, çürütülemeyen gerçek bilgiler, herkes tarafından kabul edilmiş teoriler"de yoğunlaştıkları, buna bağı olarak da her iki grubun bilim anlayışının, geleneksel olmayan bilim anlayışına aykırı ya da yetersiz olduğu görülmektedir. Kanunların oluşumu ile ilgili, öğretmen ve öğretmen adaylarının görüşlerinin "sadece kontrollü deneyler ve gözlemler" ve "bilimsel yöntem" temaları altında toplandığı görülmektedir.

Teori ve kanun arasındaki farka dair öğretmen ve öğretmen adaylarının çoğunluğu, kanunların evrensel olduğunu, teorilerinse evrensel olmadığını ifade etmiştir. Tüm bu bulgulara dayanarak fen bilimleri öğretmen ve öğretmen adaylarının, bilimin doğasının "bilimsel teoriler ve kanunlar" özelliğine yönelik geleneksel bilim anlayışına sahip oldukları söylenebilir. Aşağıda bu temayla ilgili doğrudan alıntı verilmiştir.

... "Dalton atom teorisinde atomun parçalanmayacağını söylenmiştir. Ancak daha sonra elde edilen bilgilerle atomun parçalanabileceği ispatlanmıştır (modern atom teorisi). Kanunlar ise hiçbir koşulda değişmez gerçeklerdir. Teoriler ise değişebilen gerçeklerdir..."'(FÖ-13 [Geleneksel bilim anlayışı])

Bilimsel Bilginin Yaratıcı Doğası/ Bilimsel Bilginin Sosyal ve Kültürel Yapısı/ Öznellik. Fen bilimleri öğretmenlerinin ve öğretmen adaylarının bilimin doğasının "bilimsel bilginin yaratıcı doğası", "bilimsel bilginin sosyal ve kültürel yapısı" ve "öznellik" özelliklerine yönelik görüşleriyle ilgili bulgular Tablo 8'de verilmiştir.

\section{Tablo 8.}

"Bilimsel Bilginin Yaratıcı Doğası", "Bilimsel Bilginin Sosyal ve Kültürel Yapısı" ve "Öznellik" Temasına ilişkin Bulgular

\begin{tabular}{lccc}
\hline Alt Temalar & \multicolumn{2}{c}{ Öğretmen adayı } & \multicolumn{2}{c}{$\begin{array}{c}\text { Öğretmen } \\
\text { f } \%\end{array}$} & $\mathrm{f} \%$ \\
\hline Aynı Verilere Sahip Oldukları Halde Bilim Insanlarının Farklı Sonuçlara Ulaşmalarının Sebebi \\
\hline Kişisel görüşlerinin, düşüncelerinin, bakış açılarının, 25 & 49.01 & 19 & 63.33 \\
özel kanılarının farklı olması ve bilgiyi yorumlama & & & \\
\hline
\end{tabular}


Fatma Adak, Selda BAKIR - Çukurova Üniversitesi Eğitim Fakültesi Dergisi, 46(1), 2017, 134-164

\begin{tabular}{|c|c|c|c|c|}
\hline \multicolumn{5}{|l|}{ farklılıkları } \\
\hline Kesin bilgilerin olmaması & 8 & 15.68 & 2 & 6.66 \\
\hline Hayal gücü & 6 & 11.76 & 3 & 10 \\
\hline $\begin{array}{l}\text { Bilim insanlarının çalışma alanlarının farklı olması ve } \\
\text { farklı bilgi birikimine sahip olmaları }\end{array}$ & 6 & 11.76 & 2 & 6.66 \\
\hline Aynı verilere dayalı farklı hipotezler kurmuşturlar & 6 & 11.76 & 2 & 6.66 \\
\hline Algıda seçicilik & 0 & 0 & 2 & 6.66 \\
\hline \multicolumn{5}{|l|}{ Bilimsel Bilgi Ile Bilimsel Düşünce Arasındaki Fark } \\
\hline $\begin{array}{l}\text { Bilimsel bilgi deney ve gözlemle açıklanan objektif } \\
\text { gerçekler, bilimsel düşünce öznel fikirlerdir }\end{array}$ & 22 & 41.50 & 10 & 38.46 \\
\hline $\begin{array}{l}\text { Bilimsel bilgi teoriler ve kanunlarla açıklanırken, } \\
\text { bilimsel düşünce duygu ve inançlarla açıklanır }\end{array}$ & 15 & 28.30 & 8 & 30.76 \\
\hline $\begin{array}{l}\text { Bilimsel bilgiler kanıtlanmış gerçekler, bilimsel fikirler } \\
\text { ise hayal gücü ve yaratıcılığa bağlı yeni bilimsel bilgiler } \\
\text { üretme aşaması }\end{array}$ & 8 & 15.09 & 5 & 19.23 \\
\hline Bilmiyorum & 8 & 15.09 & 3 & 11.53 \\
\hline
\end{tabular}

Tablo 8'e göre, bilim insanlarının aynı verilere sahip olmalarına rağmen farklı sonuçlar elde etmelerinin sebebi olarak öğretmen adaylarının görüşlerinin neredeyse yarısının ve öğretmen görüşlerinin ise yarısından fazlasının, "kişisel görüşlerin, bakış açılarının ve öznel kanılarının farklı olması" teması oluşturduğu belirlenmiştir. "Kesin bilgilerin olmaması, hayal gücü ve aynı verilere dayalı farklı hipotezler kurmuşturlar" cevapları da dikkat çeken temalardır.

Bilimsel bilgi ile bilimsel düşünce arasındaki farka ilişkin ise, öğretmen görüşlerinin ve öğretmen adaylarının görüşlerinin en fazla "bilimsel bilginin deney ve gözlemle açıklanan objektif gerçekler, bilimsel düşünce öznel fikirlerdir" ve "bilimsel bilgiler teoriyle açıklanırken bilimsel düşünceler inançla açıklanır" cevaplarında yoğunlaştıkları görülürken, bir kısım öğretmen ve öğretmen adayının hayal gücü ve yaratıcılığa değindikleri görülmektedir. Bulgulara dayanarak, fen bilimleri öğretmenlerinin ve öğretmen adaylarının bilimin doğasının "bilimsel bilginin yaratıcı doğası", "bilimsel bilginin sosyal ve kültürel yapısı" ve "öznellik" özelliklerine yönelik genel olarak geleneksel olmayan bilim anlayışını sergiledikleri söylenebilir. Aşağıda bu temayla ilgili örnek bir doğrudan alıntı verilmiştir.

.... "Bilim insanlarının olaya kendi çalışma alanlarından bakmasından kaynaklanır. Örneğin asteroit çarptığını iddia eden kesim gök bilimcilerken, volkanik patlamanın neden olduğunu söyleyenler doğa bilimcilerdir. Yani aynı veriyi kendi alanlarına uygun şekilde yorumlamıştırlar..."( FÖ-13 [Geleneksel olmayan bilim anlayışı])

\section{Tartışma ve Öneriler}

Araştırmada fen bilgisi öğretmen adaylarının bilimsel epistemolojik inanç ölçeği puanlarının yüksek olmasına dayanılarak fen bilgisi öğretmen adaylarının geleneksel bilimsel anlayışına sahip olduğu söylenilebilir. Literatürde, öğretmen adaylarının epistemolojik inançlarının geleneksel bilimsel anlayış yönünde olduğuna dair bazı çalışmalara rastlanmıştır (Abd-El-Khalick \& BouJaoude, 1997; Abd-El-Khalick \& Akerson, 2004; Terzi, 2005; Meral \& Çolak, 2009; Ayvacı ve Nas, 2010; Karabulut \& Ulucan, 2012). Örneğin; Meral ve Çolak (2009), teknik eğitim fakültesinde öğrenim gören 651 öğrenciyle yaptıkları çalışmaları sonucunda, öğrencilerin geleneksel bilim anlayışına sahip olduklarını belirlemişlerdir. Karabulut ve Ulucan (2012), farklı üniversitelerin beden eğitimi ve spor yüksekokullarında öğrenim görmekte olan birinci ve son sınıf beden eğitimi öğretmen adaylarının katılımıyla gerçekleştirdikleri çalışma sonucunda öğretmen adaylarının geleneksel bilimsel inançlarının yüksek düzeyde olduğunu tespit etmişlerdir.

Araştırmanın bir diğer bulgusu, fen bilimleri öğretmenlerinin bilimsel epistemolojik inançlarının da geleneksel bilim anlayışını yansıttığıdır. Literatürde öğretmenlerin epistemolojik inançlarının incelendiği bazı çalışmalar mevcuttur (Karhan, 2007; Doğan \& Abd-El-Khalick, 2008; Izgar \& Dilmaç, 2009; Kurt, 2010; Aslan \& Taşar, 2013; Bayır, 2016). Karhan (2007), öğretmenlerin epistemolojik inançlarını 
incelediği çalışması sonucunda, öğretmenlerin doğruların tek ve mutlak olduğu yönünde yüzeysel inançlara sahip olduklarını saptamıştır. Kurt (2010), 256 öğretmen ile gerçekleştirdiği araş̧ırmanın sonucunda öğretmenlerin epistemolojik inançlarının kısmen gelişmiş epistemolojik anlayışa uygun yanları olmakla birlikte, daha çok geleneksel bilim anlayışına sahip olduklarını tespit etmiştir. Doğan ve Abd-El-Khalick (2008), fen öğretmenlerinin bilimin doğasına yönelik geleneksel bilim anlayışı taşımalarının yanında, öğrencileriyle de benzer görüşlere sahip olduklarını ve bu naif görüşlerin, yaş, cinsiyet, coğrafi köken ve sosyo-ekonomik statüden bağımsız olduğunu bulmuşlardır. Aslan ve Taşar (2013), fen öğretmenleriyle yaptıkları çalışmaları sonucunda öğretmenlerin bilimin doğasının birçok alt boyutuna yönelik naif görüşlere sahip olduklarını bulmuşlardır. Aslan (2009), naif görüşün, pozitivist paradigmayı benimseyen bir görüş olduğunu belirtmektedir. Fen bilimleri öğretmenlerinin, bilimin doğasının birçok alt boyutuyla ilgili günümüz bilim anlayışından oldukça uzak oldukları sonucunu bulan, Bayır (2016), çalışmasının sonuçlarına dayanarak, 2004 ve 2013 fen programlarının vizyonu olarak öğrencilerin fen okuryazarı olarak yetişmesinin vurgulandığı düşünülürse, mevcut bulguların ülkemizin reform hareketlerini ve 21. yy fen eğitiminin beklentilerini desteklemediğini iddia etmektedir.

$\mathrm{Bu}$ araştırmanın bir diğer sonucu, fen bilimleri öğretmenleri ile fen bilgisi öğretmen adaylarının bilimsel epistemolojik inançları arasında anlamlı bir farkın olmamasıdır. Öğretmen ve öğretmen adaylarının epistemolojik inançları arasındaki ilişkiyi inceleyen Alpan ve Erdamar (2014), Gazi Üniversitesi'nde öğrenim gören 247 son sınıf öğretmen adayı ile öğretmenlik uygulamasında onlara rehberlik yapan 32 öğretmenle yaptıkları çalışmalarında, öğretmenlik uygulaması öncesi ve sonrasında öğretmen ve öğretmen adaylarının epistemolojik inançlarını incelemiş, öğretmenlerin ve öğretmen adaylarının uygulama öncesinde ve sonrasında epistemolojik inançlarının boyutları arasında anlamlı bir farkın olmadığını gözlemlemişlerdir. Saraç ve Cappellaro (2015), sınıf öğretmenleri ve öğretmen adaylarının bilimin doğasına yönelik görüşleri arasında, hipotez-teori-kanun hiyerarşisi ile bilimlerarası kavramların tutarlıı̆̆ı konuları haricinde, anlamlı bir farkın olmadığını belirtmektedirler.

Fen bilimleri öğretmenleri ve öğretmen adaylarının bilimin doğasına yönelik görüşleri, bilimin doğasının özelliklerine göre belirlenmiştir. Bilimsel bilginin kaynağına yönelik hem öğretmen adaylarıın hem de öğretmen görüşlerinin, en fazla deney ve gözlemde yoğunlaştığı görülmüştür. Bilimsel bilginin elde edilmesinde deney, gözlem gibi bilimsel metotların kullanıldığı doğru fakat eksik bir bilgidir. Bu durum bilimin doğasına yönelik kabul edilen mitlerden biridir. Bilimsel bilginin elde edilmesinde tek bir bilimsel metot olmadığı gibi, bilim insanlarının yaratıcılık ve hayal güçleri de önemlidir (Palmquist \& Finley, 1997; Abd-el-Khalick \& Akerson, 2004; Doğan, 2010). Doğan'a göre (2010), bilimsel bilginin "deney yoluyla” üretildiğini düşünmek, Francis Bacon'un savunduğu insan bilgisinin tek kaynağının deney olduğunu öne süren deneycilik bilgi kuramıyla yani pozitivist görüşle örtüşmektedir. Buna göre fen bilimleri öğretmenlerinin ve öğretmen adaylarının bilimsel bilginin kaynağına yönelik geleneksel bilim anlayışına sahip oldukları söylenebilir. Bu bulgu literatürdeki birçok çalışmayla benzerlik göstermektedir (Dickinson, Abd-El-Khalick \& Lederman, 2000; Abd-el-Khalick \& Akerson, 2004; Arı, 2010; Doğan, 2010; Dursun, 2015). Örneğin Abd-El-Khalick ve Akerson (2004), fen dersi alan 28 öğretmen adayıyla yaptığı çalışmaları sonucunda katılımcıların \%86'sının bilimsel bilginin tek ya da birbirini sırayla izleyen aşamaların oluşturduğu bilimsel metotla oluştuğunu düşündüklerini, Doğan (2010), lise öğrencilerinin büyük bir çoğunluğunun bilimsel bilginin bilimsel metotla üretildiğini söylediklerini belirtmiştir.

Fen bilimleri öğretmen ve öğretmen adaylarının, bilimin doğasının "bilimsel bilginin değişebilirliği" özelliğine yönelik, öğretmenlerin tamamının, öğretmen adaylarının ise çoğunluğunun görüşünün bilimsel bilginin değişebileceği yönünde olduğu bulunmuştur. Öğretmen adaylarının görüşlerinden çok azı ise kanunların, bilgilerin değişmeyeceği yönündedir. Buna göre öğretmen adaylarının ve fen bilimleri öğretmenlerinin bilimin doğasının "bilimsel bilginin değişebilirliği" özelliğiyle ilgili olarak geleneksel olmayan bilimsel anlayışa sahip oldukları söylenebilir. Bu görüş Lederman (1999), Doğan ve Abd-elKhalick (2008), Arı (2010) ve Aslan'ın (2009) çalışmalarından elde ettikleri sonuçlarla tutarlıdır. Örneğin, Aslan'ın (2009) bilimsel bilginin geçiciliği konusunda yaptığı çalışmada, fen ve teknoloji öğretmenlerinin yeni teknikler ve gelişmiş araçlarla tekrarlanan bilimsel çalışmalar sonucunda, bilimsel bilginin değişebileceği görüşünde oldukları tespit edilmiştir. 
Bilimin doğasının "bilimsel bilginin doğası kanıta ve gözleme dayalıdır" ve "gözlemler, çıkarımlar ve bilimde teorik başlıklar" özellikleriyle ilgili olarak, fen bilimleri öğretmen ve öğretmen adaylarının geleneksel olmayan bilim anlayışını sergiledikleri söylenebilir. Her ne kadar çalışma grubu lise öğrencileri de olsa Doğan (2010) da çalışmasının sonucunda benzer bulgulara ulaşmıştır.

Fen bilimleri öğretmen ve fen bilgisi öğretmen adaylarının, teorinin tanımına yönelik görüşlerinin en fazla, "deney ve gözlemle ispatlanmış hipotez", "doğruluğu büyük ölçüde kabul edilmiş bilgi", "herkes tarafından kabul görmemiş deney sonucu" görüşlerinde yoğunlaştıkları belirlenmiştir. Teorinin tanımıyla ilgili olarak, öğretmen adayları ve öğretmen görüşlerinden tamamının geleneksel olmayan bilimsel anlayışı yansıttığını söylemek güçtür. Çünkü her iki katılımcı grubun verdikleri cevaplar, tam anlamıyla geleneksel olmayan bilimsel anlayışı yansıtmakta yetersiz kalmaktadır. Örneğin "bilginin açıklanması", "herkes tarafından kabul görmemiş deney sonucu", henüz kanıtlanmamış bilimsel önerme" temaları her ne kadar geleneksel görüş olmasa da geleneksel olmayan bilimsel anlayış için de yetersiz kalmaktadır. Kanunla ilgili olarak ise öğretmen adaylarının ve öğretmenlerin görüşlerinin çoğunlukla, evrenselleşmiş bilgi, çürütülemeyen gerçek bilgiler, herkes tarafından kabul edilmiş teoriler gibi temalarla tamamının bilim anlayışının geleneksel olmayan bilim anlayışına aykırı ya da yetersiz olduğu görülmektedir.Teori ve kanun arasındaki farkla ilgili, öğretmen ve öğretmen adaylarının çoğunluğu, kanunların evrensel olduğunu, teorilerinse evrensel olmadığını ifade etmişlerdir. Katılımcıların teori, kanun, teori ve kanunun oluşumları ve farklarına dair görüşlerinden elde edilen bulguların tamamına dayanarak, fen bilimleri öğretmen ve öğretmen adaylarının, bilimin doğasının "bilimsel teoriler ve kanunlar" özelliğine yönelik geleneksel bilim anlayışına sahip oldukları söylenebilir. Bu bulgu Doğan (2010), Mıhladız (2010) ve Aslan'ın (2009) bulgularıyla örtüşmektedir.Bilimin doğasına yönelik bilinen mitlerden biri de hipotezlerden teorilerin, teorilerden de kanunların oluştuğu (Aslan, 2009), yani teori ve kanun arasında bir hiyerarşinin olduğudur (Dickinson, Abd-El-Khalick \& Lederman, 2000; Doğan Bora, Arslan \& Çakıroğlu, 2006). Oysa kanun ve teoriler farklı bilgi türleridir ve birbirlerine dönüşmezler (Doğan, Çakıroğlu, Bilican \& Çavuş, 2009: 25). Irez (2008) ve Doğan'a göre (2010), bu yanılgının en büyük sebeplerinden biri mevcut ders kitaplarındaki yanlış bilgilerdir.

Fen bilimleri öğretmenlerinin ve öğretmen adaylarının, bilim insanlarının kişisel görüş, hayal gücü vb. özellikleri dolayısıyla farklı bakış açılarına sahip olabilecekleri, bu nedenle de farklı sonuçlara ulaşabilecekleri görüşleriyle, "bilimsel bilginin yaratıcı doğası, sosyal ve kültürel yapısı ve öznellik" özelliklerine değindikleri görülmektedir. Bu bulgulara dayanarak, fen bilimleri öğretmenlerinin ve öğretmen adaylarının bilimin doğasının "bilimsel bilginin yaratıcı doğası", "bilimsel bilginin sosyal ve kültürel yapısı" ve "öznellik" özelliklerine yönelik, genel olarak geleneksel olmayan bilim anlayışını sergiledikleri söylenebilir. Bu bulgularla tutarlı olarak, Doğan'ın (2010) çalışmasında öğrenciler, dinozorların yok oluşu ile ilgili bilim insanlarının farklı teoriler üretmesini, eldeki verilerinin aynı olmasına rağmen ortak bir teori üzerinde karara varamamalarının sebebinin farklı araştırmalar ve farklı yorumlar olduğunu ifade etmişlerdir.Aslan'ın (2009) çalışmasında, fen ve teknoloji öğretmenlerinin büyük bir bölümü tarafından $(\% 66,2)$ "başarılı bilim insanlarının çalışmalarında daima çok açık fikirli, mantıklı, önyargısız ve nesnel olmalarının yanında hayal gücü, zeka ve dürüstlük gibi özellikleri de taşıması gerektiği" ifade edilmiştir.

Özetle, her ne kadar "Bilimsel Epistemolojik Ölçeği" nden elde edilen bulgulara göre fen bilimleri öğretmenlerinin ve öğretmen adaylarının geleneksel bilim anlayışına sahip oldukları sonucu bulunsa da, "Bilimsel Epistemoloji Üzerine Görüşler Anketi" nden elde edilen bulgulara göre, her iki grubun da bilimin doğasının "bilimsel bilginin doğası deneye dayalıdır, bilimsel teoriler ve kanunlar" özelliklerine yönelik pozitivist paradigmaya dayanan geleneksel bilim anlayışına, "bilimsel bilginin değişebilirliği, bilimse bilginin doğası kanıta ve gözleme dayalıdır, gözlemler, çıkarımlar ve bilimde teorik başlıklar, bilimsel bilginin yaratıcı doğası, öznellik ve bilimsel bilginin sosyal ve kültürel yapısı" özelliklerine yönelik ise post-pozitivist paradigmaya dayanan geleneksel olmayan (çağdaş) bilim anlayışına sahip oldukları tespit edilmiştir. Abd-El Khalick ve BouJaoude (1997), fen öğretmenlerinin hala geleneksel bilim anlayışına sahip olmalarını, öğretmen adaylarının fen öğretimi sırasında gerek duydukları bilimin doğasına yönelik bilgiyi geliştirmeleri konusunda öğretmen yetiştirme programlarının yararlı olmadığına 
bağlamaktadırlar.

$\mathrm{Bu}$ araştırmanın sonuçlarına dayanarak, fen bilimleri öğretmenlerine, bilimin doğasının bazı özelliklerine yönelik sahip oldukları geleneksel bilim anlayışından kurtarıp geleneksel olmayan bilim anlayışına yöneltmek için hizmetiçi eğitimler verilebilir. Doğan, Çakıroğlu, Çavuş, Bilican ve Arslan (2011), fen ve teknoloji öğretmenlerinin bilimin doğasına yönelik görüşlerinin hizmetiçi eğitim programları sayesinde olumlu yönde geliştiğini belirtmişlerdir. Fen bilgisi öğretmen adaylarının bilimin doğasına yönelik görüşlerini geliştirmek için de bilimin doğasına yönelik etkili yöntemler kullanılabilir. Her ne kadar Abd-El-Khalick ve Lederman (2000), yaptıkları geniş literatür incelemesi sonucunda fen öğretmenlerinin bilimin doğası hakkındaki görüşlerini güçlendirmek için dikkate alınan girişimlerin başarısız olduğu sonucunu belirtseler de, bazı yaklaşımların bu konuda etkin olduğunu belirten çalışmalar da mevcuttur (Bianchini \& Colburn, 2000; Abd-El-Khalick, 2001; Köseoğlu, Tümay \& Budak, 2008; Türköz, 2015; Tola, 2016). Örneğin Abd-El-Khalick (2001), açık yansıtıcı yaklaşımın öğretmenlerin bilimin doğası hakkındaki görüşlerini yansıtmada etkili olduğunu belirtmektedir. 


\section{References}

Abd-El-Khalick, F. (2001). Embedding nature of science instruction in preservice elementary science courses:Abandoning scientism, But...Journal of Science Teacher Education, 12(3), 215-233.

Abd-El-Khalick, F. (2002). The development of conceptions of the nature of scientific knowledge and knowing in the middle and high school years: A cross-sectional study. Paper presented at the annual meeting of the National Association for Research in Science Teaching, New Orleans, LA.

Abd-El-Khalick, F.,\& Akerson, V.L. (2004). Learning as conceptual change: Factors mediating the development of preservice elementary teachers' views of natüre of science. Science Education, 88 (5), 785-810.

Abd-El-Khalick, F.,\& BouJaoude, S. (1997). An exploratory study of the knowledge base for science teaching. Journal of Research in Science Teaching, 34(7), 673-699.

Abd-El-Khalick, F.,\& Lederman, N. (2000). The influence of history of science courses on students' views of natüre of science. Journal of Research in Science Teaching, 37(10), 1057-1095.

Akçay, B. (2011). Fen ve teknoloji öğretmenlerinin bilimin doğasına yönelik inanışları. Trakya Üniversitesi Eğitim Fakültesi Dergisi, 1(1), 145-164

Akgün, Z. (2015). Sınıf öğretmenlerinin bilimin doğasına yönelik görüşleri: Söke ilçe örneği. Yayımlanmamış Yüksek Lisans Tezi. Adnan Menderes Üniversitesi Sosyal Bilimler Enstitüsü, Aydın.

Alpan, G. ve Erdamar, G. (2014). Uygulama öğretmenlerinin ve öğretmen adaylarının epistemolojik inançlarının karşılaştırılması. Hitit Üniversitesi Sosyal Bilimler Enstitüsü Dergisi, 7 (2), 241257.

Arı, Ü. (2010). Fen bilgisi öğretmen adaylarının ve sınıf öğretmen adaylarının bilimin doğası hakkındaki görüşlerinin incelenmesi. Yayımlanmamış Yüksek Lisans Tezi. Fırat Üniversitesi, Elazığ.

Aslan, O. (2009). Fen ve teknoloji öğretmenlerinin bilimin doğası hakkındaki görüşleri ve bu görüşlerin sınıf uygulamalarına yansımaları. Yayımlanmamış Doktora Tezi, Gazi Üniversitesi Eğitim Bilimleri Enstitüsü, Ankara.

Aslan, O.,\& Tasar, M.F. (2013). How do science teachers view and teach the nature of science? A classroom investigation. Educaion \& Science, 38 (167), 65-80.

Ayaz, F. (2009). Fen bilgisi öğretmen adaylarının epistemolojik inançlarının yordanması. Yayımlanmamış Yüksek Lisans Tezi, Ege Üniversitesi Sosyal Bilimler Enstitüsü, İzmir.

Ayvacı, H.Ş. ve Nas, S. (2010). Fen ve teknoloji öğretmenlerinin bilimsel bilginin epistemolojik yapısı hakkındaki temel bilgilerini belirlemeye yönelik bir çalışma. Kastamonu Eğitim Dergisi, 18(3), 691-704.

Bayır, E. (2016). Fen bilimleri öğretmenlerinin bilimin doğasına ilişkin görüşleri: Bilişsel harita örneği. Kastamonu Eğitim Dergisi, 24(3), 1419-1436.

Bianchini, J. A.,\& Colburn, A. (2000). Teaching the nature of science through inquiry to prospective elementary teachers: A tale of two researchers. Journal of Research in Science Teaching, 37, 177-209.

Büyüköztürk, Ş., Çakmak, E.K., Akgün, Ö.E., Karadeniz, Ş. ve Demirel, F. (2009). Bilimsel araştırma yöntemleri. Ankara: Pegem Akademi.

Cevizci, A. (2010). Felsefe Ansiklopedisi (6. Baskı). İstanbul: Paradigma Yayıncılık.

Chan, K-W. (2002). Students' epistemological beliefs and approaches to learning. Paper presented at the AARE Conference. Brisbane, Australia. Available at: http://www.aare.edu.au/02pap/cha02007.htm

Christensen, L.B., Johnson, R.B., \& Turner, L.A. (2015).Araştırma yöntemleri desen ve analiz (A. Aypay, Çev.Edt.). Ankara: ANI Yayıncılık.

Çoban, G.Ü.,\& Ergin, Ö. (2008). The instrument for determining the views of primary school students about scientific knowledge. Elementary Education Online, 7(3), 706-716.

Çüçen, K. A. (2001). Bilgi Felsefesi. Bursa: Asa Kitapevi. 
Deryakulu, D. (2004). Üniversite öğrencilerinin öğrenme ve ders çalışma stratejileri ile epistemolojik inançları arasındaki ilişki. Kuram Ve Uygulamada Eğitim Yönetimi, 10(38),230-249.

Deryakulu, D. (2006). Epistemolojik inançlar, eğitimde bireysel farklılıklar (2.Baskı). Editör: Yıldız Kuzgun ve Deniz Deryakulu, 261-290, Ankara: Nobel Yayınevi.

Deryakulu, D. ve Bıkmaz, H.F. (2003). Bilimsel Epistemolojik İnançlar ölçeğinin geçerlilik ve güvenilirlik çalışması. Eğitim Bilimleri ve Uygulama, 2(4),243-257.

Deryakulu, D. ve Büyüköztürk, Ş. (2005). Epistemolojik inanç ölçeğinin faktör yapısının yeniden incelenmesi: cinsiyet ve öğrenim görülen program türüne göre epistemolojik inançların karşılaştırılması. Eğitim Araştırmaları, 18, 57-70.

Dickinson, V. L.,Abd-El-Khalick, F. S., \&Lederman, N. G. (2000).Changing Elementary Teachers' Views of the NOS: Effective Strategies for Science Methods Courses. Research Reports. ED441680

Doğan, N. (2010). Farklı Lisede Okuyan 11. Sınıf öğrencilerinin bilimin doğası hakkındaki bakış açılarının karşılaştırılması. Gazi Üniversitesi Eğitim Fakültesi Dergisi, 30(2), 533-560.

Doğan, N.,\& Abd-El-Khalick, F. (2008). Turkish grade 10 students' and science teachers' conceptions of nature of science: A national study. Journal of Research in Science Teaching, 45 (10), 10831112.

Doğan Bora, N., Arslan, O. ve Çakıroğlu, J. (2006). Lise öğrencilerinin bilim ve bilim insani hakkındaki görüşleri. Hacettepe Üniversitesi Eğitim Fakültesi Dergisi, 31, 32-44

Doğan, N., Çakıroğlu, J., Bilican, K. ve Çavuş, S. (2009). Bilimin doğası ve öğretimi. Ankara: Pegem Akademi.

Doğan N., Çakıroğlu J., Çavuş S., Bilican K. ve Arslan O. (2011). Öğretmenlerin bilimin doğası hakkındaki görüşlerinin geliştirilmesi: Hizmetiçi eğitim programının etkisi. Hacettepe Üniversitesi Eğitim Fakültesi Dergisi, 40, 127-139.

Dursun, B. (2015). Fen bilgisi öğretmen adaylarının bilimin doğası ve teknoloji hakkındaki görüşlerinin incelenmesi.Yayımlanmamış Yüksek Lisans Tezi. İnönü Üniversitesi Eğitim Bilimleri Enstitüsü, Malatya.

Ekiz, D. (2009). Bilimsel araştırma yöntemleri. Ankara: Anı Yayıncılık.

Eroğlu, S.E. ve Güven, K. (2006). Üniversite öğrencilerinin epistemolojik inançlarının bazı değişkenler açısından incelenmesi. Selçuk Üniversitesi Sosyal Bilimler Enstitüsü Dergisi, 16.

Evcim, i. (2010). ilköğretim 8. Sınıf öğrencilerinin epistemolojik inanışlarıyla, fen kazanımlarını günlük yaşamlarında kullanabilme düzeyleri ve akademik başarıları arasındaki ilişki.Yayımlanmamış Yüksek Lisans Tezi, Marmara Üniversitesi Eğitim Bilimleri Enstitüsü, İstanbul.

Gürol, A., Altunbaş, S. ve Karaaslan, N. (2010). Öğretmen adaylarının öz-yeterlilik ve epistemolojik inançları üzerine bir çalışma. 9. Ulusal Sınıf Öğretmenliği Eğitimi Sempozyumu, Elazığ, 20-22 Mayıs.

Hançerlioğlu, O. (1996). Felsefe Sözlüğü. (10. Baskı). İstanbul: Remzi Kitabevi.

Hofer, B. K. (2001). Personal Epistemology Research: Implications for Learning and Teaching.Journal of Educational Psychology Review. 13 (4), 353-83.

Hofer, B.K.,\& Pintrich P.R. (1997). The development of epistemological theories: Beliefs about knowledge and knowing and their relation to learning. Review of Educational Research. 67(1), 88-140

Irez, S. (2008). Nature of science as depicted in Turkish biology textbooks. Science Education, 93,( 3), 422-447.

Izgar, H. ve Dilmaç, B. (2008). Yönetici adayı öğretmenlerin özyeterlilik algıları ve epistemolojik inançlarının incelenmesi. Selçuk Üniversitesi Sosyal Bilimler Enstitüsü Dergisi, 20, 437-446.

Karabulut, E.O. ve Ulucan, H. (2012). Beden eğitimi öğretmen adaylarının bilimsel epistemolojik inançlarının farklı değişkenler açısından incelenmesi. Spor ve Performans Araştırmaları Dergisi, 3(2).

Karhan, A. (2007). ilköğretim okullarında görev yapan öğretmenlerin epistemolojik inançlarının demografik özelliklerine ve bilgi teknolojilerini kullanma durumuna göre incelenmesi, Yayınlanmamış Doktora Tezi, Yıldız Teknik Üniversitesi Sosyal Bilimler Enstitüsü Eğitim Bilimleri Anabilim Dalı Eğitim Programları ve Öğretim programları, İstanbul. 
Khishfe, R.,\& Abd-El-Khalick, F. (2002). Influence of explicit and reflective versus implicit inquiry-oriented instruction on sixth graders' views of nature of science. Journal of Research In Science Teaching, 39(7), 551-578.

Köseoğlu, F., Tümay, H. ve Budak, E. (2008). Bilimin doğası hakkındaki paradigma değişimleri ve öğretimi ile ilgili yeni anlayışlar. Gazi Üniversitesi Gazi Eğitim Fakültesi Dergisi, 28(2), 221-237.

Kurt, C. (2010) Öğretmenlerin epistemolojik inançları ve değişime direnme tutumları arasındaki ilişkilerin incelenmesi. Yayımlanmamış Yüksek Lisans Tezi,Gazi Üniversitesi Eğitim Bilimleri Enstitüsü Eğitim Yönetimi ve Denetimi Bilim Dalı, Ankara.

Lederman, N.G. (1992). Students' and teachers' conceptions about the nature of science: A review of the research. Journal of Research in Science Teaching, 29, 331-359.

Lederman, N. G. (1999). Teachers' understanding of the nature of science and classroom practice: factors that facilitate or impede the relationship. Journal ofResearch in Science Teaching. 36(8). 916-929

MEB (2013). Ilköğretim Kurumları (illkokul ve Ortaokul) Fen Bilimleri Dersi $(3,4,5,6,7$ ve 8. Sınıflar) Öğretim Programı. Ankara: Milli Eğitim Bakanlığı.

Meral, M. ve Çolak, E. (2009). Öğretmen adaylarının bilimsel epistemolojik inançlarının incelenmesi. Ondokuz Mayıs Üniversitesi Eğitim Fakültesi Dergisi, 27, 129-146.

Mıhladız, G. (2010). Fen bilgisi öğretmen adaylarının bilimin doğası konusundaki pedagojik alan bilgilerinin araştırılması.Yayımlanmamış Yüksek Lisans Tezi, Gazi Üniversitesi, Eğitim Bilimleri Enstitüsü, Ankara.

Miles, M. B.,\& Huberman, A. M. (1994). Qualitative data analysis. (Second Edition). Thousand Oaks: Sage Publications.

Muis, K. R., Bendixen, L. D., \& Haerle, F. C. (2006). Domain-generality and domainspecificityin personal epistemology research: philosophical and empirical reflections in the development of a theoretical framework. EducationalPsychology Review, 18(1), 3-54.

Öngen, D. (2003). Epistemolojik inançlar ile problem çözme stratejileri arasındaki ilişkiler: eğitim fakültesi öğrencileri üzerinde bir çalışma, Eğitim Araştırmaları Dergisi, 3(13),155-162.

Özden, Y. (2003). Öğrenme ve öğretme. Ankara: PegemA Yayıncılık.

Öztürk, G. (2009). Öğretmen adaylarının çevre okuryazarlıklarının epistemolojik inançları vasıtasıyla incelenmesi. Yayımlanmamış Yüksek Lisans Tezi, Orta Doğu Teknik Üniversitesi Sosyal Bilimler Enstitüsü, Ankara.

Öztürk, N. (2011). Fen bilimleri öğretmen adaylarının sosyalbilimsel konulara ilişkin kritik düşünme yeteneklerinin, epistemolojik inançlarının, üstbilişsel farkındalıklarının incelenmesi: Nükleer enerji santralleri örneği. Yayımlanmamış Yüksek Lisans Tezi, Orta Doğu Teknik Üniversitesi, Ankara.

Palmquist, B. C.,\& Finley, F. N. (1997). Preservice teachers' views of the nature of science during a postbaccalaureate science teaching program. Journal of Research in Science Teaching, 34, 595-615.

Patton, M.Q. (2014). Nitel araştırma ve değerlendirme yöntemleri (M.Bütün, S.B.Demir, Çev.Edts). Ankara: PegemA.

Pomeroy, D. (1993). Implications of teachers' beliefs about the nature of science: Comparison of the beliefs of scientist, secondary science teachers, and elemantery teachers. Science Education, $77(3), 261-278$.

Saraç, E.,\& Cappellaro, E. (2015). Views of the elementary teachers and pre-service elementary teachers on the nature of science. Mediterranean Journal of Humanities, 2, 331-349.

Schommer, M. (1990). Effects of beliefs about the nature of knowledge on comprehension. Journal of Educational Psychology, 82(3), 498-504.

Schommer, M.,\& Walker, K. (1997). Epistemological beliefs and valuing school: considerations for college admissions and retention. Research in HigherEducation, 38(2), 173-186.

Terzi, A. R. (2005). Üniversite öğrencilerinin bilimsel epistemolojik inanışları üzerine bir araştırma. Afyon Kocatepe Üniversitesi Sosyal Bilimler Enstitüsü Dergisi, 7(2), 298-311. 
Tola, Z. (2016). Argümantasyon öğretiminin ortaokul 6.sınıf öğrencilerinin madde ve ısı ünitesine yönelik kavramsal anlama, bilimsel düşünme ve bilimin doğası anlayışlarına etkisi. Yayımlanmamış Yüksek Lisans Tezi, Kocaeli Üniversitesi, Fen Bilimleri Enstitüsü, Kocaeli.

Türköz, G.Ö. (2015). Bilimin doğası etkinliklerinin öğrencilerin kavramsal anlama, bilimsel süreç becerileri ve bilimin doğası anlayışlarına etkisi. Yayımlanmamış Yüksek Lisans Tezi, Pamukkale Üniversitesi, Eğitim Bilimleri Enstitüsü, Denizli.

Yazıcı, S. (1999). Felsefeye giriş. İstanbul: Alfa Yayınları.

Yıldırım, C. (2014). Bilim felsefesi. Ankara: Remzi Kitabevi.

Yıldırım, A. ve Şimşek, H. (2008). Sosyal bilimlerde nitel araştırma yöntemleri.Ankara: Seçkin Yayıncılık.

Yılmaz, K. ve Delice, A. (2007). Öğretmen adaylarının epistemolojik ve problem çözme inançlarının problem çözmeye sürecine etkisi. XVI. Ulusal Eğitim Bilimleri Kongreleri, Gaziosmanpaşa Üniversitesi, Tokat. 